\title{
Effects of molasses-based liquid feed supplementation to a high-straw dry cow diet on feed intake, health, and performance of dairy cows across the transition period
}

\author{
C. D. Havekes, ${ }^{1}$ T. F. Duffield, ${ }^{2}$ (1) A. J. Carpenter, ${ }^{1}{ }^{\oplus}$ and T. J. DeVries ${ }^{1 *}{ }^{1}$ \\ ${ }^{1}$ Department of Animal Biosciences, University of Guelph, Guelph, Ontario, N1G 2W1, Canada \\ ${ }^{2}$ Department of Population Medicine, University of Guelph, Guelph, Ontario, N1G 2W1, Canada
}

\begin{abstract}
The objective of this study was to determine the effects of adding molasses-based liquid feed to a highstraw dry cow diet on intake, behavior, health, and performance of dairy cows across the transition period. Holstein cows $(\mathrm{n}=40)$ entering their second lactation or greater were enrolled at dry-off $(\sim 45 \mathrm{~d}$ before expected calving) and assigned to 1 of 2 treatments: a high-straw dry cow total mixed ration (TMR) with either (1) no molasses [CON; $\mathrm{n}=20 ; 10.7 \%$ crude protein (CP), $1.45 \mathrm{Mcal} / \mathrm{kg}$ of net energy for lactation $\left(\mathrm{NE}_{\mathrm{L}}\right)$ ] or (2) supplemented with $1 \mathrm{~kg} /$ cow daily [dry matter (DM) basis] of molasses-based liquid feed (LF; $\mathrm{n}=20 ; 11.2 \% \mathrm{CP}, 1.49 \mathrm{Mcal} / \mathrm{kg}$ of $\left.\mathrm{NE}_{\mathrm{L}}\right)$. At calving all cows were fed the same lactating TMR $(14.9 \% \mathrm{CP}$, $1.68 \mathrm{Mcal} / \mathrm{kg}$ of $\mathrm{NE}_{\mathrm{L}}$ ) and followed for $28 \mathrm{~d}$. During the dry period, cows fed the LF diet had greater DM intake $(15.3 \pm 0.24$ vs. $13.4 \pm 0.24 \mathrm{~kg} / \mathrm{d})$ and tended to have a shorter interval between meals $(192.8 \pm 8.38$ vs. $216.5 \pm 7.97 \mathrm{~min})$ and more frequent meals $(6.3 \pm$ 0.27 vs. $5.6 \pm 0.27$ meals $/$ d), while consuming their feed faster $(0.09 \pm 0.001$ vs. $0.08 \pm 0.001 \mathrm{~kg}$ of $\mathrm{DM} /$ min) compared with cows fed the CON diet. Regardless of treatment, cows sorted $[100 \% \times($ actual intake/predicted intake)] against the longest ration particles ( $>19$ $\mathrm{mm}$ ), with cows fed the CON diet sorting more against these $(81.1 \pm 2.6$ vs. $93.9 \pm 2.6 \%)$. Cows fed the CON diet did not sort for or against short particles $(<8,>4$ $\mathrm{mm} ; 100.2 \pm 0.31 \%)$, but cows fed the LF diet tended to sort against these $(99.2 \pm 0.31 \%)$. Post-calving, cows fed the LF diet did not sort for long particles (98.5 \pm $1.1 \%$ ), but cows fed the CON diet continued to sort against these $(96.3 \pm 1.1 \%)$. Cows fed the LF diet had higher mean reticulorumen $\mathrm{pH}$ in the dry period $(6.4 \pm$ 0.05 vs. $6.2 \pm 0.06 \mathrm{pH})$, in the first week after calving $(\mathrm{CON}=5.7 \pm 0.06 \mathrm{pH}, \mathrm{LF}=5.8 \pm 0.06 \mathrm{pH})$, and
\end{abstract}

Received December 19, 2019.

Accepted February 6, 2020.

*Corresponding author: tdevries@uoguelph.ca tended to have higher mean reticulorumen $\mathrm{pH}$ in the second week after calving $(\mathrm{CON}=5.7 \pm 0.06 \mathrm{pH}, \mathrm{LF}=$ $5.9 \pm 0.06 \mathrm{pH}$ ). The results suggest that supplementing a molasses-based liquid feed in high-straw dry cow diets may improve intake and consistency in nutrients consumed during the dry period and in early lactation, as well as possibly promoting better rumen health across the transition period.

Key words: dry cow diet, molasses, sorting behavior

\section{INTRODUCTION}

In the weeks leading up to calving and in early lactation, various metabolic and behavioral challenges are imposed on the dairy cow (Drackley, 1999). One of the greatest stressors the cow will face is the sudden and dramatic demand for nutrients, which is commonly followed by a lag in DMI. As a result of not being able to consume sufficient DM to meet the high nutrient demand for milk production, cows fall into an energydeficient state referred to as negative energy balance (Herdt, 2000). During periods of excessive negative energy balance, cows become more susceptible to developing metabolic disease such as ketosis, metritis, displaced abomasum, and mastitis (Ingvartsen, 2006).

To minimize the severity of negative energy balance and thereby reduce the risk of metabolic disease, considerable research has focused on transition cow feeding strategies. Much recent research has focused on the dry cow diet, with a particular recent focus on the concept of controlling energy consumption during the dry period in an attempt to maintain BCS while promoting consistent intake (Dann et al., 2006; Janovick et al., 2011). From a physiological standpoint, these diets, which often contain a large proportion of straw, are successful in promoting energy balance by reducing body fat mobilization. From a feeding behavior standpoint, one limitation to these diets is that the high straw content may be filling and may also increase the risk of feed sorting. Recent research has focused on manipulating the physical characteristics of these dry 
cow diets to promote consistency in intake and reduce sorting (Havekes et al., 2020a,b). That research demonstrated that using a smaller screen size $(2.54-\mathrm{cm}$ screen vs. 10.16-cm screen) to chop wheat straw in a highstraw (29\%) dry diet increased DMI, reduced sorting, and improved metabolic health post-calving (Havekes et al., 2020a). Similarly, adding water to a high-straw dry diet (36\% wheat straw), with straw chopped with a 2.54-cm screen, also increased DMI and reduced sorting during the dry period compared with the diet with no water added, and improved rumen $\mathrm{pH}$ around the time of calving (Havekes et al., 2020b). Despite reductions in sorting and improvements in DMI, approximately 5 to $10 \%$ refusals against the long forage particles still occurred in those studies, and cows still experienced a reduction in DMI as they approached calving. Thus, room still exists for improving consistency in intake of high-straw dry cow diets, both within and across days, as cows approach calving.

Sorting of TMR may be minimized by feeding management, reducing forage particle size, and the strategic use of liquids (e.g., water- and molasses-based liquid feeds; Miller-Cushon and DeVries, 2017). When added to a lactating cow ration, a molasses-based liquid feed supplement improved intake and reduced sorting (DeVries and Gill, 2012). Potential may exist for molasses-based liquid feeds to reduce sorting and promote greater DMI of high-straw dry cow diets. Furthermore, sugar supplementation supports microbial growth, especially for fiber-digesting bacteria (Oba, 2011), which can promote more rapid fiber degradation and lead to greater DMI. Molasses supplementation has been shown to have a positive influence on the metabolic status of ewes around the time of lambing (Moallem et al., 2016). Ewes fed the supplemental molasses lost less body condition and had greater blood glucose and lower BHB and nonesterified fatty acid (NEFA) concentrations before lambing (Moallem et al., 2016). Provision of supplementary sugar through a molassesbased liquid feed supplement, therefore, has potential benefits across the transition period. Litherland et al. (2013) supplemented molasses at a rate of $0.85 \mathrm{~kg}$ of $\mathrm{DM} /$ cow per day in a high-straw (30\% of ration DM) dry cow diet and reported greater feed efficiency for those cows post-calving but no differences in sorting. It is possible that a greater inclusion rate of molassesbased liquid feed could improve intake and reduce feed sorting, thereby improving consistency in intake.

Thus, the objective of this study was to quantify the effects of molasses-based liquid feed supplementation to a high-straw dry cow diet on the sorting behavior, nutrient intake, metabolic status, and productivity of dairy cows across the transition period. It was hypothesized that pre-calving supplementation of molasses-based liquid feed in the TMR of dry cows would reduce sorting activity while increasing DMI, rumination time, and rumen health, resulting in improved metabolic status and production of cows after calving.

\section{MATERIALS AND METHODS}

Forty Holstein cows (parity $=1.9 \pm 1.04$; mean \pm SD) were used in this study, which took place at the University of Guelph Elora Research Station-Dairy Facility (Elora, ON, Canada). This study was performed in conjunction with the study described by Havekes et al. (2020b), with both studies sharing the same group of control cows $(\mathrm{n}=20)$. Cows were dried off and enrolled in the study at approximately $45 \mathrm{~d}$ before expected calving (actual $=43.2 \pm 5.87 \mathrm{~d}$ ). The use of cows and experimental procedures complied with the guidelines of the Canadian Council on Animal Care (2009) and were approved by the University of Guelph Animal Care Committee (Protocol \#3628).

During the dry period, cows were housed in 1 of 2 dry cow pens and trained to eat out of individually assigned automated feed bins (Insentec B.V., Marknesse, the Netherlands). Both pens contained cows receiving either of the treatment diets throughout the duration of the study. The dry cow pens each had 12 automated feed bins, 24 freestalls (mattress base bedded with chopped wheat straw), and 2 water troughs. The stocking density of the pens never exceeded 12 cows, ensuring that each cow had access to its own lying stall and automated feed bin. Cows were moved to an individual maternity pen $(3.5 \times 4.9 \mathrm{~m})$ upon signs of calving $(3.6$ $\pm 3.7 \mathrm{~d}$ before calving; mean $\pm \mathrm{SD}$ ), where they had individual access to feed and water. After calving, cows were milked in their individual maternity pen using a portable milking system for $4.7 \pm 1.9 \mathrm{~d}$, after which they moved to their lactating pen, where they were again assigned to an individual feeding bin. The lactating pen had 15 automated feed bins, 30 freestalls, and 2 water troughs. The stocking density never exceeded 15 cows, which ensured that all cows had access to their own feed bin and lying stall. Lactating cows were milked in a rotary milking parlor (DeLaval, Tumba, Sweden) twice daily at 0430 and $1615 \mathrm{~h}$.

\section{Experimental Design}

Sample size and power analyses were used to calculate (as per Morris, 1999) the minimum number of replicates needed per treatment $(n=20)$ to detect a $10 \%$ level of observed mean difference for the primary outcome variables, including DMI, feeding behavior, 
and feed sorting. Estimates of variation for these variables were based on previously reported values (Coon et al., 2018; Dancy et al., 2019; Havekes et al., 2020a).

Upon dry-off, cows were randomly assigned withinpen to 1 of 2 dietary treatments (Table 1): a dry cow TMR with either (1) no molasses added $(\mathbf{C O N} ; \mathrm{n}=$ 20) or (2) a molasses-based liquid feed supplement $(\mathbf{L F} ; \mathrm{n}=20$; Custom Transition Blend, Liquid Feeds International Ltd., Innerkip, ON, Canada) added at a rate of $1.0 \mathrm{~kg} /$ cow per day on a DM basis $(\sim 2.0$ $\mathrm{kg}$ /cow per day as fed). The molasses blend contained sugarcane molasses, condensed whey, a 50/50 blend of condensed fermented corn extractives and condensed corn distillers solubles, magnesium chloride, and sulfuric acid. Magnesium chloride and sulfuric acid were added to balance the high naturally occurring level of potassium in molasses and to bring the DCAD level to an acceptable range. The DCAD levels were similar across treatment diets (Table 1 ) and fell within the recommended acceptable range of -10 to $-15 \mathrm{mEq} / 100 \mathrm{~g}$ DM for dry cow feeding programs (Constable et al., 2017). Treatment allocation was balanced for parity and previous $305-\mathrm{d}$ milk production $(10,419 \pm 1,541 \mathrm{~kg}$; mean $\pm \mathrm{SD}$ ). Both treatment diets were fed ad libitum for the entire dry period and were formulated using AMTS.Cattle.Professional 4.10.5 (Agricultural Modeling and Training Systems, Groton, NY) to target an energy consumption of $20.8 \mathrm{Mcal} / \mathrm{cow}$ per day of $\mathrm{NE}_{\mathrm{L}}$ for the CON treatment and $22.9 \mathrm{Mcal} / \mathrm{cow}$ per day of $\mathrm{NE}_{\mathrm{L}}$ for the LF treatment. For the LF treatment, the liquid feed addition to the diet proportionally diluted the percentage of other dietary ingredients within the diet, which resulted in the LF diet having slightly lower fiber and starch levels, slightly greater $\mathrm{NE}_{\mathrm{L}}$, and, by design, greater sugar levels (Table 1). As per research facility standard operating procedures, urine $\mathrm{pH}$ levels of randomly selected dry cows were routinely measured by the herd's veterinary technician to monitor the effectiveness of the negative DCAD feeding program. The ration was adjusted if urine $\mathrm{pH}$ values deviated from the target $\mathrm{pH}$ values of 5.5 to 6 . Wheat straw included in the dry diet was chopped using a bale processor (Haybuster Model H-1150, Jamestown, ND) using a 2.54-cm screen. Base diets containing corn silage, straw, and dry cow concentrate were prepared in a mixer wagon (Jaylor Model 5572, Jaylor Fabricating, Orton, ON, Canada) and then transferred to individual feed carts (Super Data Ranger, American Calan, Northwood, $\mathrm{NH}$ ). The CON treatment was then fed as is, whereas for the LF treatment, molasses was added, through an overhead double-headed sprayer, at the appropriate amount relative to batch size and cow numbers. The diet was continuously mixed as the molasses was added and continued to be mixed for approximately 3 to 5 min afterward. The CON diet continued mixing during this time to ensure that the diets were mixed for a similar duration of time. Upon calving (d 1), all cows were fed the same lactating cow ration (Table 1) once daily between 0800 and $0900 \mathrm{~h}$. The lactating diet was formulated to meet the nutrient requirements of dairy cows producing $36 \mathrm{~kg} / \mathrm{d}$ (NRC, 2001), and cows were followed for $28 \mathrm{~d}$ after calving.

To ensure that the automated feed bins did not overflow, both treatment diets were fed twice daily (half fed between 0900 and $1000 \mathrm{~h}$ and the other half fed between 1500 and $1600 \mathrm{~h}$ ). Dry cow bins were cleaned out daily at approximately $0900 \mathrm{~h}$, and feed amounts were adjusted daily to target $10 \%$ refusals per bin (actual $=16.4 \pm 11.8 \%$, on a DM basis). The total amount of lactating feed offered was adjusted daily to target approximately $10 \%$ refusals per bin (actual $=13.1 \pm$ $11.32 \%$, on a DM basis).

\section{Behavioral Data Collection}

An electronic monitoring system (HR-TAG-LD, SCR Engineers Ltd., Netanya, Israel), as validated by Schirmann et al. (2009), was used to monitor rumination activity. These rumination data loggers, attached to a nylon collar, were fitted on the cows before enrollment in the study. Rumination activity was recorded $24 \mathrm{~h} / \mathrm{d}$ during the entire dry period and for $4 \mathrm{wk}$ after calving. Data were continuously uploaded to a control unit through the radio frequency reader. Raw data were stored in 2-h intervals and then combined into a continuous record to determine the total time spent ruminating each day.

The automated feed bins facilitated DMI and feeding behavior data collection, as validated by Chapinal et al. (2007). From the recorded data, measurements included duration of each visit to the feed bin, amount of feed consumed (start weight minus end weight) during each visit, and rate of consumption for each visit. These data were then summarized to calculate DMI $(\mathrm{kg} / \mathrm{d})$, time spent feeding $(\mathrm{min} / \mathrm{d})$, and feeding rate $(\mathrm{kg} / \mathrm{min})$. Individual feeding bouts were combined and separated into meals using a meal criterion (minimum duration of time between meals) calculated for each cow. Meal criteria for both the dry period and the lactating period were calculated for each cow using methods described by DeVries et al. (2003); in summary, a software package (MIX 3.1.3; MacDonald and Green, 1988) was used to fit normal distributions to the frequency of $\log _{10^{-}}$ transformed intervals between feeding visits. If the time between 2 feed bin visits exceeded the determined meal criterion, this was classified as a different meal. The 
Table 1. Ingredient and chemical composition (mean $\pm \mathrm{SD}$ ) of the dry cow treatment and the lactating cow TMR

\begin{tabular}{|c|c|c|c|}
\hline Composition & Control dry diet & Liquid feed dry diet & Lactating diet \\
\hline \multicolumn{4}{|l|}{ Ingredient (\% DM) } \\
\hline Corn silage $^{1}$ & 41 & 39 & 30 \\
\hline Wheat straw ${ }^{2,3}$ & 36 & 33 & 2 \\
\hline Alfalfa haylage $^{4}$ & - & - & 30 \\
\hline High-moisture corn ${ }^{5}$ & - & - & 24 \\
\hline Dry cow supplement ${ }^{6}$ & 23 & 22 & - \\
\hline Lactating cow supplement $^{7}$ & - & - & 14 \\
\hline Molasses $^{8}$ & - & 6 & - \\
\hline \multicolumn{4}{|l|}{ Chemical composition } \\
\hline DM $(\%)$ & $53.5 \pm 3.02$ & $53.7 \pm 2.80$ & $45.0 \pm 1.92$ \\
\hline $\mathrm{CP},(\%$ of $\mathrm{DM})$ & $10.7 \pm 0.76$ & $11.2 \pm 0.37$ & $14.9 \pm 0.58$ \\
\hline $\mathrm{ADF}(\%$ of $\mathrm{DM})$ & $32.1 \pm 1.13$ & $30.0 \pm 1.43$ & $19.9 \pm 1.35$ \\
\hline NDF ( $\%$ of DM) & $49.7 \pm 1.71$ & $47.1 \pm 1.86$ & $29.6 \pm 2.0$ \\
\hline TDN (\% of DM) & $63.9 \pm 2.43$ & $62.8 \pm 1.21$ & $73.4 \pm 1.99$ \\
\hline Lignin $(\%$ of DM) & $3.6 \pm 0.34$ & $3.2 \pm 0.36$ & $2.7 \pm 0.31$ \\
\hline Starch (\% of DM) & $16.1 \pm 0.98$ & $15.6 \pm 0.75$ & $28.3 \pm 1.76$ \\
\hline Fat $(\%$ of DM) & $2.1 \pm 0.34$ & $2.3 \pm 0.25$ & $3.7 \pm 0.47$ \\
\hline $\operatorname{Ash}(\%$ of $\mathrm{DM})$ & $7.4 \pm 0.36$ & $7.9 \pm 0.48$ & $6.6 \pm 0.35$ \\
\hline $\mathrm{Ca}(\%$ of $\mathrm{DM})$ & $1.2 \pm 0.11$ & $1.0 \pm 0.10$ & $0.9 \pm 0.06$ \\
\hline $\mathrm{P}(\%$ of $\mathrm{DM})$ & $0.3 \pm 0.02$ & $0.3 \pm 0.03$ & $0.45 \pm 0.02$ \\
\hline $\mathrm{K}(\%$ of $\mathrm{DM})$ & $1.0 \pm 0.10$ & $1.1 \pm 0.19$ & $1.5 \pm 0.11$ \\
\hline $\mathrm{Na}(\%$ of $\mathrm{DM})$ & $0.1 \pm 0.02$ & $0.1 \pm 0.02$ & $0.4 \pm 0.03$ \\
\hline $\mathrm{Mg}(\%$ of $\mathrm{DM})$ & $0.4 \pm 0.04$ & $0.4 \pm 0.04$ & $0.5 \pm 0.02$ \\
\hline $\mathrm{Cl}(\%$ of $\mathrm{DM})$ & $0.8 \pm 0.02$ & $0.9 \pm 0.02$ & $0.6 \pm 0.14$ \\
\hline $\mathrm{S}(\%$ of $\mathrm{DM})$ & $0.4 \pm 0.04$ & $0.3 \pm 0.04$ & $0.2 \pm 0.01$ \\
\hline $\operatorname{DCAD}^{9}(\mathrm{mEq} / 100 \mathrm{~g})$ & $-14.8 \pm 2.05$ & $-11.4 \pm 3.80$ & $25.0 \pm 3.62$ \\
\hline Sugar $(\%$ of DM) & $3.8 \pm 0.34$ & $6.4 \pm 0.90$ & $3.6 \pm 0.34$ \\
\hline ME (Mcal/kg of DM) & $2.14 \pm 0.03$ & $2.18 \pm 0.03$ & $2.57 \pm 0.02$ \\
\hline $\mathrm{NE}_{\mathrm{L}}(\mathrm{Mcal} / \mathrm{kg}$ of DM) & $1.45 \pm 0.02$ & $1.49 \pm 0.3$ & $1.68 \pm 0.03$ \\
\hline
\end{tabular}

${ }^{1}$ Corn silage had a DM of $33.8 \%$ and chemical composition (DM basis) of $7.4 \pm 0.49 \%$ CP, $22.0 \pm 1.33 \%$ ADF, and $40.6 \pm 0.03 \%$ NDF. Particle size distribution $(\%$ of DM) $=21.3 \pm 10.56 \%$ long $(>19 \mathrm{~mm}), 61.7 \pm 10.68 \%$ medium $(<19,>8 \mathrm{~mm}), 9.8 \pm 0.55 \%$ short $(<8,>4 \mathrm{~mm})$, and $7.2 \pm 2.63 \%$ fine $(<4 \mathrm{~mm})$ particles.

${ }^{2}$ Dry ration straw (chopped with a $2.54-\mathrm{cm}$ screen) had a DM of $90.3 \%$ and chemical composition (DM basis) of $5.6 \pm 0.50 \% \mathrm{CP}, 51.2 \pm 2.57 \% \mathrm{ADF}$, and $78.4 \pm 2.35 \%$ NDF. Particle size distribution (\% of DM) $=3.0 \pm$ $2.62(>19 \mathrm{~mm}), 35.9 \pm 4.78 \%$ medium $(<19,>8 \mathrm{~mm}), 26.7 \pm 3.86 \%$ short $(<8,>4 \mathrm{~mm}), 33.6 \pm 9.22 \%$ fine $(<4 \mathrm{~mm})$ particles.

${ }^{3}$ Lactating straw had a DM of $88.0 \%$ and chemical composition (DM basis) of $5.6 \pm 0.23 \% \mathrm{CP}, 51.7 \pm 0.60 \%$ $\mathrm{ADF}$, and $80.5 \pm 0.39 \%$ NDF. Particle size distribution $(\%$ of $\mathrm{DM})=13.4 \pm 7.67 \%$ long $(>19 \mathrm{~mm}), 39.1 \pm$ $6.34 \%$ medium $(<19,>8 \mathrm{~mm}), 21.5 \pm 3.81 \%$ short $(<8,>4 \mathrm{~mm})$, and $26.0 \pm 5.46 \%$ fine $(<4 \mathrm{~mm})$ particles.

${ }^{4}$ Alfalfa haylage had a DM of $38.2 \%$ and chemical composition (DM basis) of $18.7 \pm 0.96 \% \mathrm{CP}, 32.7 \pm 0.41 \%$ $\mathrm{ADF}$, and $40.2 \pm 0.27 \% \mathrm{NDF}$. Particle size distribution $(\%$ of $\mathrm{DM})=27.5 \pm 5.82$ long $(>19 \mathrm{~mm}), 55.0 \pm$ $7.25 \%$ medium $(<19,>8 \mathrm{~mm}), 9.7 \pm 1.33 \%$ short $(<8,>4 \mathrm{~mm}), 7.8 \pm 1.33 \%$ fine $(<4 \mathrm{~mm})$ particles.

${ }^{5}$ High-moisture corn had a DM of $71.0 \%$ and chemical composition (DM basis) of $9.6 \pm 0.22 \% \mathrm{CP}, 2.7 \pm 0.34 \%$ $\mathrm{ADF}$, and $7.8 \pm 0.49 \% \mathrm{NDF}$.

${ }^{6}$ Supplied by Floradale Feed Mill Ltd. (Floradale, ON, Canada) including (as fed) $24.0 \%$ soybean meal, $13.0 \%$ Animate (Phibro, Teaneck, NJ), $13.0 \%$ beet pulp, $10.0 \%$ high-bypass soybean meal, $10 \%$ ground soy hulls, $9.0 \%$ limestone calcium carbonate, $5.96 \%$ bran, $4.8 \%$ canola, $3.0 \%$ molasses, $1.60 \%$ calcium sulfate, $1.4 \%$ Diamond V Yeast XP (Diamond V, Cedar Rapids, IA), $1.0 \%$ inorganic dry premix, $0.95 \%$ magnesium oxide, $0.75 \%$ integral, $0.75 \%$ fine salt, $0.6 \%$ monocalcium phosphate, $0.15 \%$ granular sulfur, $0.04 \%$ Rumensin/Coban (Elanco, Greenfield, IN). Dry cow supplement had a DM of $91.2 \%$ and chemical composition (DM basis) of $26.3 \pm 0.70 \% \mathrm{CP}, 13.7 \pm 0.42 \% \mathrm{ADF}$, and $25.1 \pm 0.75 \% \mathrm{NDF}$.

${ }^{7}$ Supplied by Floradale Feed Mill Ltd. including (as fed) $40.0 \%$ soybean meal, $30.0 \%$ SoyPlus (Landus Cooperative, Ames, IA), $10.0 \%$ canola, $4.0 \%$ sodium sesquicarbonate, $2.9 \%$ fine salt, $2.9 \%$ limestone calcium carbonate, $2.4 \%$ wheat shorts, $1.6 \%$ magnesium oxide, $1.4 \%$ monocalcium phosphate, $1.4 \%$ Diamond V Yeast XP (Diamond V), 1.0\% tallow, 1.0\% DCAD+, 0.8\% urea, 0.7\% inorganic premix, 0.6\% MetaSmart (Adisseo, Alpharetta, GA), 0.2\% granular sulfur, 0.04\% Rumensin/Coban (Elanco), 0.04\% Selplex 2000 (Alltech, Nicholasville, KY). Lactating cow supplement had a DM of $90.5 \%$ and chemical composition (DM basis) of $37.8 \pm 1.29 \% \mathrm{CP}, 9.5 \pm 0.11 \% \mathrm{ADF}$, and $15.9 \pm 0.23 \% \mathrm{NDF}$.

${ }^{8}$ Custom transition liquid molasses blend (Liquid Feeds International, Innerkip, ON, Canada) had a DM of $47.9 \pm 2.07 \%$ and a chemical composition (DM basis) of $16.6 \pm 1.81 \% \mathrm{CP}, 1.2 \pm 0.13 \%$ calcium, $0.9 \pm 0.08 \%$ phosphorous, $4.0 \pm 0.13 \%$ potassium, and $35.0 \pm 7.7 \%$ total sugars as invert.

${ }^{9}$ DCAD calculated using the following equation: $\mathrm{mEq} / 100 \mathrm{~g}$ of $\mathrm{DM}=[(\% \mathrm{Na} \div 0.023)+(\% \mathrm{~K} \div 0.039)]-[(\%$ $\mathrm{Cl} \div 0.0355)+(\% \mathrm{~S} \div 0.016)]$ 
number of different meals in a day was termed meal frequency (no./d). Total daily meal time was the time between the start of the first bin visit until the end of the last bin visit each day, minus all of the non-feeding intervals greater than the length of the meal criterion that occurred that day. Meal length (min/meal) was calculated as the total daily meal time divided by meal frequency. Finally, meal size $(\mathrm{kg} / \mathrm{d})$ was calculated as daily DMI divided by meal frequency.

\section{Health Data Collection}

Cow BW was recorded using a walk-over scale (DeLaval, Tumba, Sweden) at dry-off, 14 and $7 \mathrm{~d}$ before calving, and 7 and $25 \mathrm{~d}$ post-calving. Additionally, BCS was visually assessed and recorded using a 5-point scale, as described by Wildman et al. (1982). To reduce variability, one observer recorded BCS for the duration of the study, and all measurements were taken before feeding $(1000 \mathrm{~h}$ for dry cows and $0900 \mathrm{~h}$ for lactating cows).

Wireless telemetry boluses (eBolus, eCow Ltd., Devon, UK) were used to measure reticulorumen $\mathrm{pH}$ (as validated by Falk et al., 2016). The boluses were orally administered to 30 cows using a balling gun at least 3 wk before calving $(\mathrm{CON} \mathrm{n}=15 ; \mathrm{LF} \mathrm{n}=15)$. Data consisted of reticulorumen $\mathrm{pH}$ data points, at 15-min intervals, $24 \mathrm{~h} / \mathrm{d}$ throughout the trial period. Data were downloaded weekly and amalgamated into a continuous record for each individual cow. Time spent below a pH threshold of 5.8 and 6.0 and area under the curve (AUC) at a 5.8 and $6.0 \mathrm{pH}$ threshold were then calculated, along with daily mean, minimum, and maximum $\mathrm{pH}$ values. Values for AUC were also standardized for intake by dividing those values by DMI for each day for each cow.

Blood BHB and glucose measurements were taken on $\mathrm{d}-14,-7,1,4,7,10,13,19$, and 25 relative to calving and analyzed using an electronic hand-held device (FreeStyle Precision Neo, Abbott Diabetes Care, Saint Laurent, QC, Canada), as validated by Kanz et al. (2015) and Wittrock et al. (2013), respectively. Blood glucose levels obtained from the FreeStyle Precision Neo device were then corrected using the equation [0.6 $+(0.86 \times$ glucometer reading $)]$, as per Wittrock et al. (2013). Blood samples were taken $14 \mathrm{~d}$ before calving to ensure that if cows calved early they would have pre-calving data; however, samples taken more than $7 \mathrm{~d}$ before calving were discarded. Further, blood calcium, NEFA, and haptoglobin were assessed on $\mathrm{d}-14,-7$, 1 , and 7 relative to calving. Again, any samples taken more than $7 \mathrm{~d}$ before calving were discarded, and only the most recent sample relative to calving was used in the analysis. Throughout the study, all blood collection occurred before feed delivery (1000 h for dry cows and $0900 \mathrm{~h}$ for lactating cows). Blood samples were taken from the coccygeal vein and were collected into a 10-mL red top evacuated tube. All blood samples were left to sit at room temperature for a period of $1 \mathrm{~h}$ following collection, to allow coagulation and to facilitate fibrinogen breakdown. After $1 \mathrm{~h}$, samples were centrifuged at $1,500 \times g$ at $18^{\circ} \mathrm{C}$ for 15 min to separate cells from serum. For each blood sample, $1.5 \mathrm{~mL}$ of serum were placed into $3-\mathrm{mL}$ tubes and stored at $-20^{\circ} \mathrm{C}$ until the time of analysis. Serum samples were sent to the Animal Health Laboratory, University of Guelph (Guelph, ON, Canada), where they were analyzed for NEFA (reagent supplied by Randox Laboratories, Crumlin, UK), glucose (reagent supplied by Roche Diagnostics, Indianapolis, IN), calcium (reagent supplied by Roche Diagnostics), and haptoglobin (reagent created and shared by the J. G. Skinner Laboratory, Veterinary Investigation Centre, Aberdeen, Scotland) using a photometric test on the Roche Cobas 6000 c501 instrument (Roche Diagnostics).

\section{Milk Yield and Components}

Daily milk weights were recorded by the milking parlor software (DeLaval, Tumba, Sweden) for the $4 \mathrm{wk}$ post-calving period. Starting at 5 DIM, milk samples were collected from each cow at each milking on 2 consecutive days; thus, 2 samples were taken on each of $\mathrm{d}$ $5,6,12,13,19,20,26$, and 27 . These samples were sent to a DHI testing laboratory (CanWest DHI, Guelph, ON, Canada) for component analysis (fat, protein, MUN, and SCC) using a Fourier-transform infrared full-spectrum analyzer (Milkoscan FT+ and Milkoscan 6000; Foss Analytics, Hillerød, Denmark). Daily values were averaged and adjusted based on milk weights per milking, creating 1 value per cow per day.

The results from the milk composition samples were also used to determine the yield of $4 \% \mathrm{FCM}(\mathrm{kg} / \mathrm{d})$, calculated as $[0.4 \times$ milk yield $(\mathrm{kg} / \mathrm{d})]+[15.0 \times$ fat yield $(\mathrm{kg} / \mathrm{d})]$ (NRC, 2001), and ECM (kg/d) calculated as $(0.327 \times \mathrm{kg}$ of milk $)+(12.95 \times \mathrm{kg}$ of fat $)+(7.2$ $\times \mathrm{kg}$ of protein) (Tyrrell and Reid, 1965). Lastly, efficiency of milk production was calculated as kilograms of milk, 4\% FCM yield, and ECM yield per kilogram of DMI per cow.

\section{Feed Sampling and Analysis}

Samples of each diet (dry treatment diets and lactating diet) were taken in duplicate twice a week throughout the study. The first sample was collected to determine 
particle size distribution, and the second to determine DM and chemical composition. The diet components were also all sampled individually twice monthly to be analyzed for DM, chemical composition, and particle size distribution of forages. Orts (refusal) samples were collected twice weekly from each cow, during both the dry and the lactating periods, to determine particle distribution for calculation of sorting. Liquid molasses samples were also taken on a monthly basis. All feed and liquid molasses samples were immediately frozen at $-20^{\circ} \mathrm{C}$ until further analysis.

Following a 24-h period of thawing, particle size analysis of both the fresh and orts TMR samples was conducted using a 4-screen Penn State Particle Separator (PSPS; Heinrichs, 2013; Maulfair and Heinrichs, 2013). The PSPS separated the sample into 4 fractions based on particle size: long $(>19 \mathrm{~mm})$, medium $(<19$, $>8 \mathrm{~mm})$, short $(<8,>4 \mathrm{~mm})$, and fine $(<4 \mathrm{~mm})$. Following particle separation, samples were oven-dried at $55^{\circ} \mathrm{C}$ for $48 \mathrm{~h}$. Particle size distribution and nutrient content by particle size of the offered experimental dry diets and the lactating cow diet are shown in Table 2.

The sorting of each PSPS fraction was calculated as the ratio of the actual amount of feed consumed of each fraction to the predicted amount of feed consumed of that fraction, expressed as a percentage (Leonardi and Armentano, 2003). For each fraction, as determined by the PSPS analyses, the actual amount consumed was calculated by subtracting the DM refused from the DM offered. The predicted amount consumed for each fraction was calculated as the product of the DMI of the total diet multiplied by the DM percentage of that fraction in the fed TMR. Sorting values equal to $100 \%$ indicate no sorting of the particle fraction; values $<100 \%$ indicate sorting against that particle size fraction, and values $>100 \%$ indicate sorting in favor of that particle fraction.

Fresh TMR samples, feed components, and fresh TMR PSPS fractions were collected for nutrient composition analyses. After these samples were oven-dried at $55^{\circ} \mathrm{C}$ for $48 \mathrm{~h}$, they were ground to pass through a 1-mm screen (Model 4 Wiley Laboratory Mill, Thomas Scientific, Swedesboro, NJ). Ground samples, pooled by week, were then sent to A and L Laboratory Services Inc. (London, ON, Canada) for analysis of ash $\left(550^{\circ} \mathrm{C}\right.$; AOAC International, 2000, method 942.05), ADF (AOAC International, 2000, method 973.18), NDF with heat-stable $\alpha$-amylase and sodium sulfite

Table 2. Particle size distribution (mean $\pm \mathrm{SD}$ ) and nutrient content (mean $\pm \mathrm{SD}) \times$ particle size of the fresh experimental diets ${ }^{1}$

\begin{tabular}{|c|c|c|c|}
\hline Item & $\mathrm{CON}$ & LF & $\mathrm{LAC}$ \\
\hline \multicolumn{4}{|c|}{$\%$ of DM retained on screen } \\
\hline Long & $8.2 \pm 5.19$ & $8.3 \pm 4.56$ & $8.8 \pm 3.89$ \\
\hline Medium & $53.5 \pm 5.79$ & $53.1 \pm 4.92$ & $49.3 \pm 4.11$ \\
\hline Short & $17.2 \pm 1.98$ & $17.2 \pm 1.40$ & $16.7 \pm 1.58$ \\
\hline Fine & $21.2 \pm 3.03$ & $21.4 \pm 2.59$ & $25.2 \pm 3.45$ \\
\hline \multicolumn{4}{|c|}{$\mathrm{ADF}^{2}(\%$ of screen $\mathrm{DM})$} \\
\hline Long & $40.0 \pm 1.76$ & $33.3 \pm 1.20$ & $32.6 \pm 1.72$ \\
\hline Medium & $30.9 \pm 1.94$ & $29.9 \pm 2.18$ & $25.6 \pm 1.67$ \\
\hline Short & $35.5 \pm 0.87$ & $32.5 \pm 0.94$ & $15.8 \pm 0.37$ \\
\hline Fine & $28.9 \pm 1.33$ & $26.4 \pm 1.91$ & $11.6 \pm 0.25$ \\
\hline \multicolumn{4}{|c|}{$\mathrm{NDF}^{2}(\%$ of screen DM) } \\
\hline Long & $59.6 \pm 2.14$ & $52.7 \pm 2.08$ & $44.5 \pm 1.25$ \\
\hline Medium & $47.9 \pm 3.09$ & $46.7 \pm 2.03$ & $35.1 \pm 0.92$ \\
\hline Short & $54.6 \pm 0.30$ & $51.7 \pm 1.76$ & $25.1 \pm 0.44$ \\
\hline Fine & $44.4 \pm 1.99$ & $40.1 \pm 3.07$ & $18.4 \pm 0.27$ \\
\hline \multicolumn{4}{|c|}{ Sugar $^{2}$ (\% of screen DM) } \\
\hline Long & $1.9 \pm 0.28$ & $6.4 \pm 2.79$ & $3.0 \pm 0.63$ \\
\hline Medium & $4.7 \pm 0.44$ & $6.5 \pm 0.46$ & $3.1 \pm 0.46$ \\
\hline Short & $3.4 \pm 0.06$ & $5.9 \pm 0.10$ & $3.4 \pm 0.27$ \\
\hline Fine & $3.4 \pm 0.20$ & $6.5 \pm 0.28$ & $3.4 \pm 0.04$ \\
\hline $\operatorname{peNDF}_{8 \mathrm{~mm}}{ }^{3}(\%)$ & $30.5 \pm 2.03$ & $28.7 \pm 1.66$ & $17.2 \pm 1.00$ \\
\hline $\operatorname{peNDF}_{4 \mathrm{~mm}} 3(\%)$ & $39.0 \pm 1.50$ & $36.8 \pm 1.21$ & $22.1 \pm 1.02$ \\
\hline
\end{tabular}

${ }^{1}$ Particle size was determined by processing feed samples with the Penn State Particle Separator, which has a 19-mm screen (long), 8-mm screen (medium), 4-mm screen (short), and a pan (fine). CON = control, dry diet with no molasses supplementation $(\mathrm{n}=54) ; \mathrm{LF}=$ liquid feed-supplemented diet, dry diet with molasses supplementation at a rate of $1.0 \mathrm{~kg} /$ cow per day $(\mathrm{n}=52) ; \mathrm{LAC}=$ lactation diet for both groups.

${ }^{2}$ Values were obtained from chemical analysis of TMR samples separated by particle size with a Penn State Particle Separator.

${ }^{3}$ peNDF $=$ physically effective NDF; ration NDF multiplied by sum total $\%$ of DM retained on all screens $>4$ $\mathrm{mm}\left(\mathrm{peNDF}_{4 \mathrm{~mm}}\right)$ and $>8 \mathrm{~mm}\left(\mathrm{peNDF}_{8 \mathrm{~mm}}\right)$, respectively. 
(AOAC International, 2000, method 2002.04), CP (N × 6.25; AOAC International, 2000, method 990.03; Leco FP-628 Nitrogen Analyzer, Leco Corp., St. Joseph, MI), starch (heat-stable amylase and amyloglucosidase; AOAC International, 2000, method 996.11), fat (using pet ether; AOAC International, 2000, method 920.39), lignin (using $\mathrm{ADF}$ residue and $\mathrm{H}_{2} \mathrm{SO}_{4}$ ), and minerals (using aquaregia digestion inductively coupled plasma atomic emission spectroscopy), and calculation of TDN and net energy (using NRC, 2001 equations). All liquid feed samples were sent to SDK Laboratories (Hutchinson, KS) for analysis of DM (AOAC International, 2000, method 966.20), CP (AOAC International, 2000, method 976.06), calcium and potassium (AOAC International, 2000, method 968.08), phosphorous (AOAC International, 2000, method 965.17), and total sugars as invert (AOAC International, 2000, method 968.28).

\section{Statistical Analyses}

All statistical analyses were conducted using SAS 9.4 software (SAS Institute Inc., 2013). Feeding behaviors and intake from 1 cow on the CON treatment were removed from analysis because an injury prevented her access to an automated feed bin; she died at $\mathrm{d} 18$ due to an injury that occurred $1 \mathrm{~d}$ post-calving. Starting at $\mathrm{d}$ 7 , cows were routinely tested for elevated BHB by farm staff using Keto-Test milk strips (KetoLac BHB, Sanwa Kagaku Kenkyusho Co., Higashi-Ku, Nagoya, Japan). Blood BHB and glucose measurements only up to d 7 were included in statistical analyses, because of inconsistencies across cows in propylene glycol treatment by farm staff. Due to technical failure of reticulorumen $\mathrm{pH}$ boluses, complete data sets were not available for all cows, and analyses were conducted using a sample size of 25 cows $(\mathrm{CON} n=10 ; \mathrm{LF} \mathrm{n}=15)$. Significance was declared at $P \leq 0.05$, and tendencies were reported if $0.05<P \leq 0.10$. If the $P$-value of an interaction term was $\leq 0.05$, it was retained; otherwise, interaction terms were removed from the model. Data were screened for normality using the UNIVARIATE procedure of SAS before analyses; most variables met the assumptions for normality except for SCC, NEFA, and haptoglobin. The natural logarithm of these variables was calculated and used to achieve normality. Additionally, time spent below $\mathrm{pH} 5.8$ and 6.0, and AUC calculations, were corrected using the square root function to achieve normality. A value of 1 was added to all values before these transformations, to ensure the square root could be calculated for all data points equal to 0. Backtransformed values of time spent below a $\mathrm{pH}$ of 5.8 and 6.0, AUC, SCC, NEFA, and haptoglobin are reported in the Results section. For all linear regression models described, normality and homoscedasticity of residuals were checked to assess and ensure model fit.

To investigate the effects of dietary treatment on DMI, feeding behavior, feed sorting, rumination, blood metabolites, reticulorumen $\mathrm{pH}$, milk production, and milk composition, data were first organized by cow status (dry or lactating) and then summarized either by day or by week (depending on sampling frequency). Data were then analyzed using the MIXED procedure of SAS, by status, treating week or day as a repeated measure and cow as the subject of the repeated statement. The models included the fixed effects of week or day, treatment, and the week or day $\times$ treatment interaction. Previous 305-d milk production, parity, and BW were added to the milk production and component models. Enrollment BW was added as a covariate to the DMI model in the dry period, and post-calving BW was added as a covariate for the DMI model in the lactating period. Covariance structure for each model was selected on the basis of best fit according to Schwarz's Bayesian information criterion; these covariance structures included compound symmetry, heterogeneous compound symmetry, first-order autoregressive, and heterogeneous first-order autoregressive. The PDIFF option was used in the LSMEANS statement for analyzing differences between treatments within week, when week $\times$ treatment interactions were detected. To determine the occurrence of sorting within treatments, the summarized data for each particle size were averaged by week and tested for a difference from 100 using $t$-tests, using the previously described MIXED procedure model. Differences in particle distribution between the offered treatment dry diets were tested using the MIXED procedure of SAS.

To determine whether BW and BCS were affected by dietary treatment, models were created using the MIXED procedure of SAS, wherein BW and BCS at enrollment, before calving, post-calving, and at the end of the trial were used as the dependent variables and treatment was used as a fixed effect. The change in BW and BCS were also calculated at 3 time points: (1) from dry-off to pre-calving, (2) from pre-calving to end of trial, and (3) from post-calving to the end of the trial.

As demonstrated by Rathbun et al. (2017), maximum BHB levels can be used to make inferences about metabolic health. As such, to determine whether maximum BHB was affected by treatment, data were analyzed using the MIXED procedure, wherein the highest BHB value per cow was used as the dependent variable, with treatment as a fixed effect.

As it is commonly reported that DMI drops in the week before calving (Grummer, 1995; Drackley, 1999), the change in DMI $d-7$ to $d-1$ was modeled. To ac- 
Table 3. Effect of molasses-based liquid feed supplementation throughout the dry period on various measures of feeding behavior recorded across the dry period and the first $28 \mathrm{~d}$ of lactation (mean $\pm \mathrm{SE}$ )

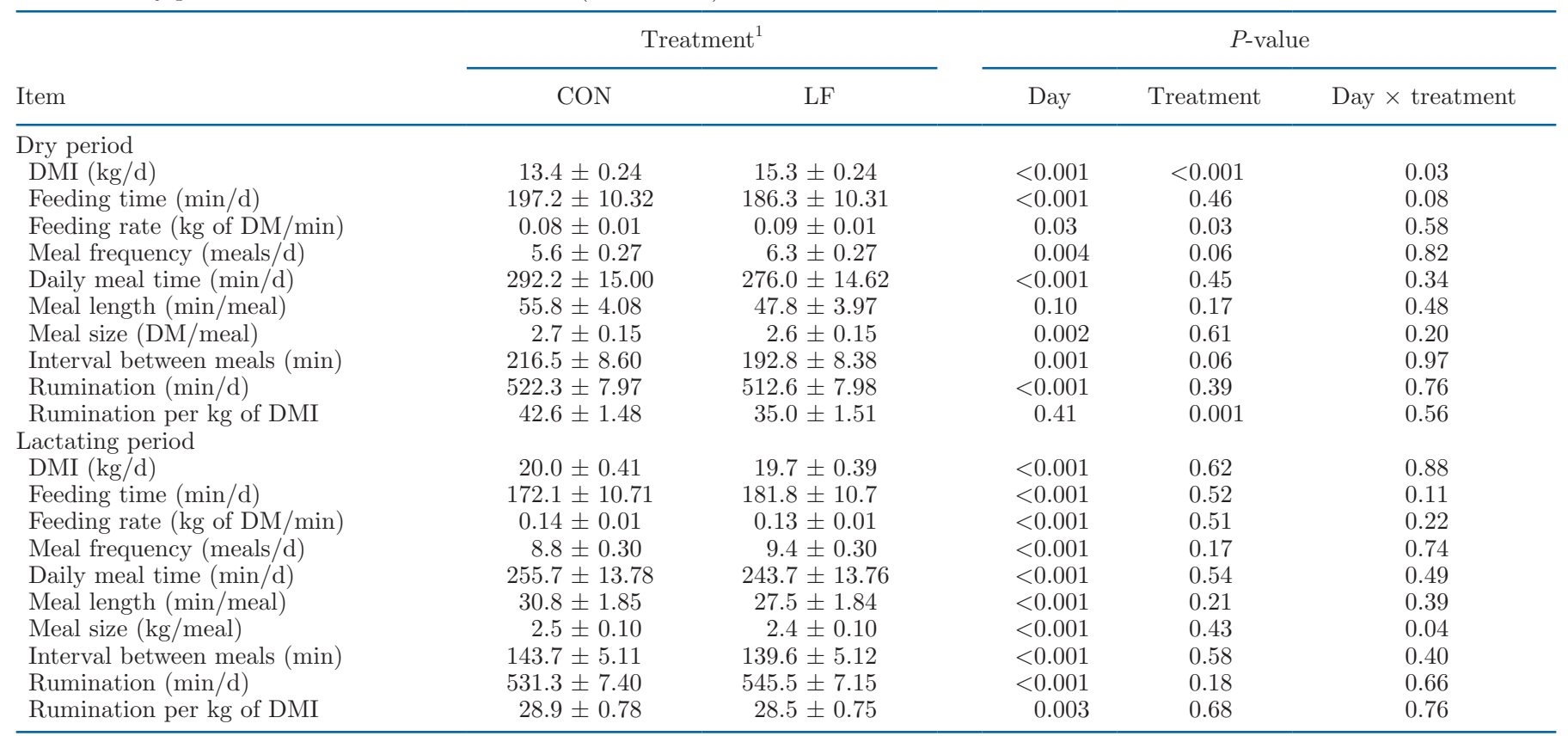

${ }^{1} \mathrm{CON}=$ control, dry diet with no molasses supplementation $(\mathrm{n}=20 \mathrm{cows}) ; \mathrm{LF}=$ liquid feed-supplemented diet, dry diet with molasses supplementation at a rate of $1.0 \mathrm{~kg} / \mathrm{cow}$ per day $(\mathrm{n}=20 \mathrm{cows})$.

complish this, an analysis of covariance was conducted, to determine any significant linear, quadratic, or cubic effects of day (Schwaiger et al., 2013; DeVries et al., 2014). This was done by using the MIXED procedure of SAS. The fixed effects of treatment, day, treatment $\times$ day, day ${ }^{2}$, treatment $\times$ day $^{2}$, day $^{3}$, and treatment $\times$ day $^{3}$ were tested, with the random effect of cow. Starting with the highest-order term, those terms that were non-significant $(P>0.05)$ were removed from the model in a stepwise manner until only significant $(P \leq$ $0.05)$ terms remained in the model. When an interaction was significant, the lesser-order term was removed. It is also well documented that the rumen environment will follow a trend similar to that of DMI, with rumen $\mathrm{pH}$ dropping following the transition from a low-energy to a high-energy diet (Humer et al., 2015). To account for this, the change in rumen $\mathrm{pH}$ in the first week after calving was modeled using the approach described above.

\section{RESULTS}

\section{Dry Period}

We detected no differences in the particle distribution of the offered experimental diets (Table 2) for the long $(P=0.92)$, medium $(P=0.72)$, short $(P=0.83)$, and fine $(P=0.71)$ particles. Cows fed the LF diet had greater DMI during the dry period compared with cows fed the CON diet (Table 3; Figure 1). The change in DMI in the week leading up to calving was modeled, and the fitted data indicated treatment differences for the quadratic coefficients $(P<0.001$; Figure 2$)$, with cows fed the CON diet experiencing a greater drop in DMI during this time period. Cows fed the LF diet ate faster and tended to have more meals per day than did cows fed the CON diet (Table 3). No difference in rumination time was detected, although cows fed the LF diet ruminated less per $\mathrm{kg}$ of DMI than did cows fed the CON diet.

During the dry period, across treatments, cows sorted against the longest ration particles (>19 mm; Table 4). Cows fed the CON diet sorted against these longest ration particles to a greater extent than did cows fed the LF diet. Cows fed both the CON and LF diets sorted in favor of medium-length particles $(<19,>8 \mathrm{~mm})$, but cows fed the CON diet tended to sort more than did cows fed the LF diet. Cows fed the CON diet did not sort for or against the short $(<8,>4 \mathrm{~mm})$ dietary particles, but cows fed the LF diet sorted against these particles. Regardless of treatment, cows sorted against the fine $(<4 \mathrm{~mm})$ dietary particles.

During the dry period cows fed the LF diet had a higher mean reticulorumen $\mathrm{pH}$ (Table 5; Figure 3) and higher minimum and maximum reticulorumen $\mathrm{pH}$ ( $\mathrm{Ta}-$ ble 5). No differences between treatments were detected 

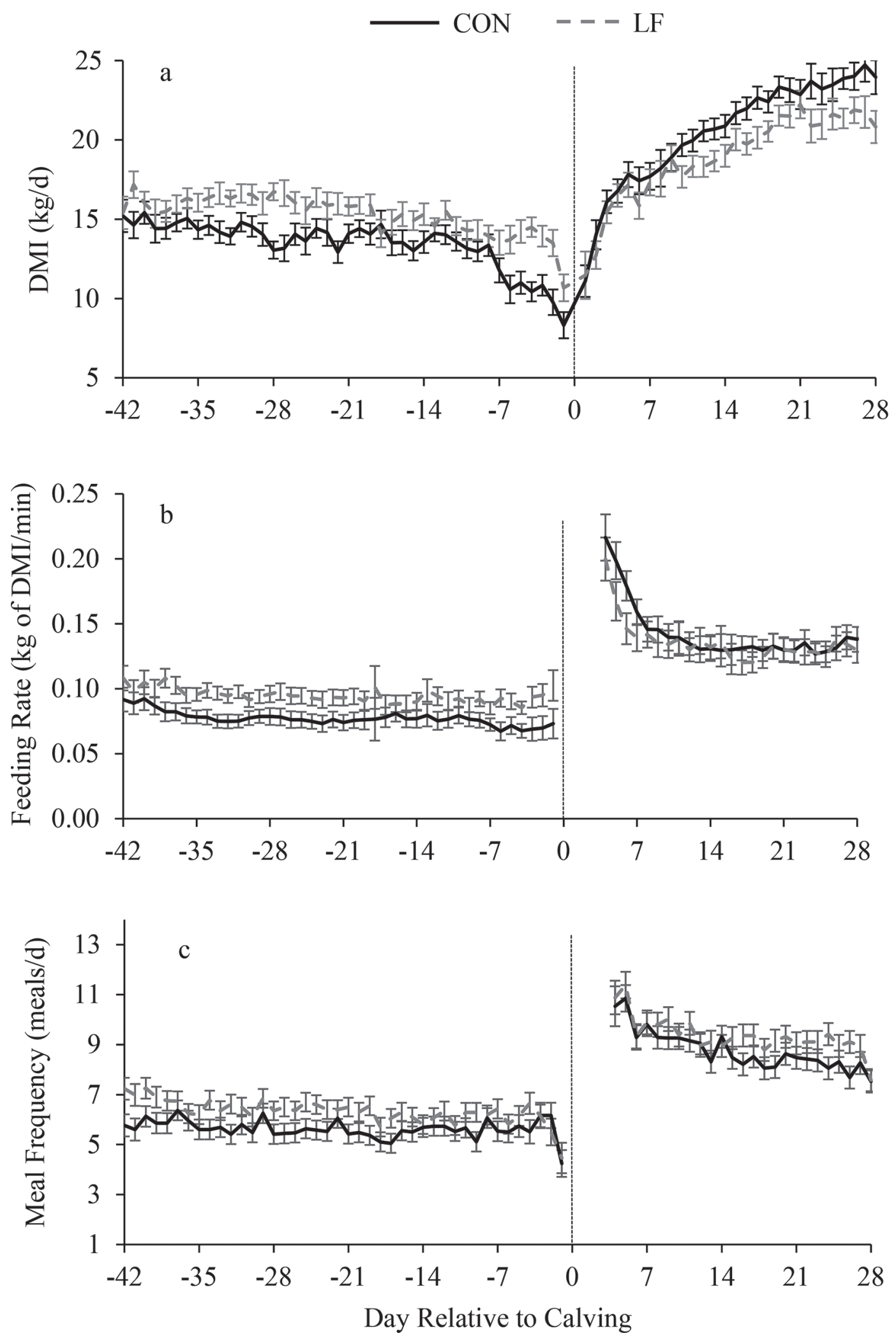

Figure 1. Mean $( \pm \mathrm{SE})$ daily (a) DMI $(\mathrm{kg} / \mathrm{d})$, (b) feeding rate $(\mathrm{kg}$ of DMI $/ \mathrm{min})$, and (c) meal frequency (meals/d) for cows fed 1 of 2 dietary treatments during the dry period: $\mathrm{CON}=$ control, dry diet with no molasses supplementation $(\mathrm{n}=20)$; LF $=$ liquid feed-supplemented diet, dry diet with molasses supplementation at a rate of $1.0 \mathrm{~kg} /$ cow per day $(\mathrm{n}=20)$. Upon calving all cows were fed the same lactating cow ration. Vertical line represents calving. 


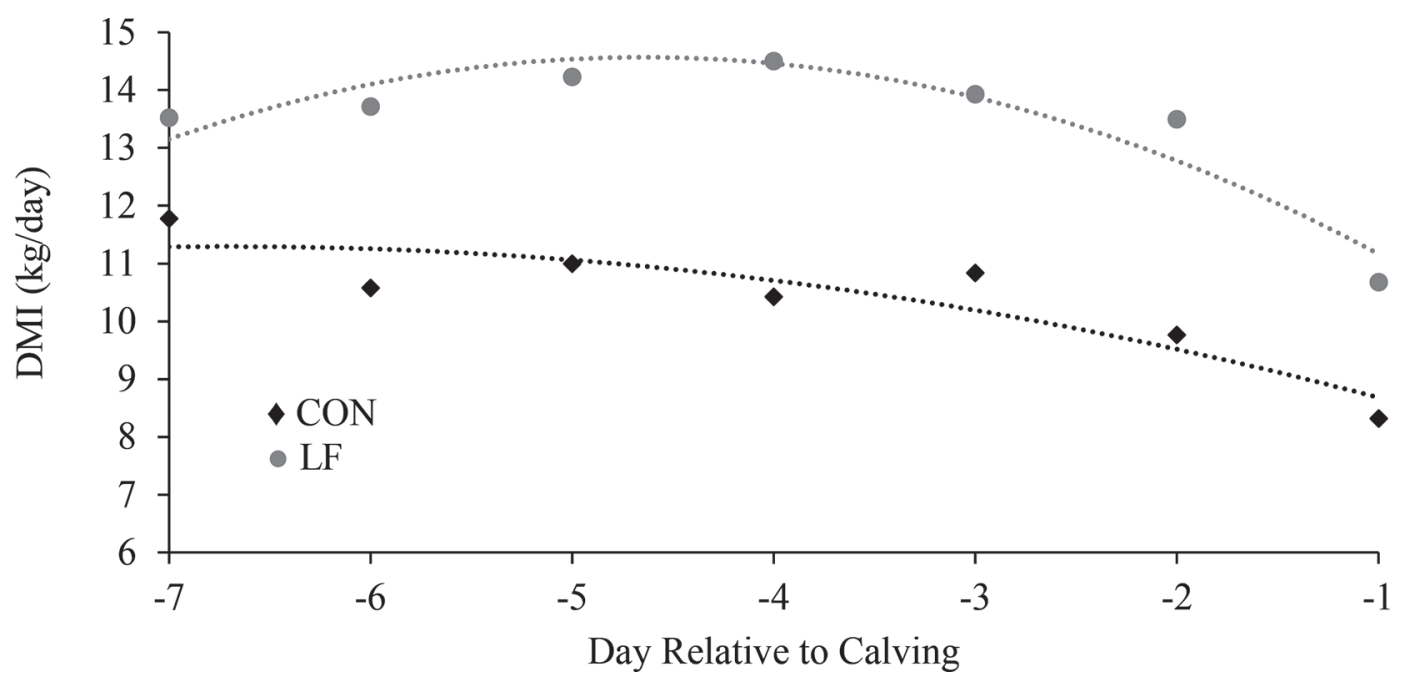

Figure 2. Mean daily DMI in the week leading up to calving for cows fed 1 of 2 dietary treatments during the dry period: CON $=$ control, dry diet with no molasses supplementation $(\mathrm{n}=20) ; \mathrm{LF}=$ liquid feed-supplemented diet, dry diet with molasses supplementation at a rate of $1.0 \mathrm{~kg} /$ cow per day $(\mathrm{n}=20)$. Upon calving all cows were fed the same lactating cow ration. Trend lines were constructed using analysis of covariance $y=-2.38 d-0.26 d^{2}+9.04\left(R^{2}=0.88\right)$ for LF; $y=-1.08 d-0.08 d^{2}+7.68\left(R^{2}=0.81\right)$ for CON.

in any blood metabolites measured (Table 6) during the dry period. Body weight was not detected to be different between treatments at dry-off and throughout the dry period (Table 7).

\section{Lactating Period}

During the first $28 \mathrm{~d}$ of lactation, we detected no differences in DMI between dry period dietary treatments, or in any measures of feeding behavior or rumination activity (Table 3). The loss in BW over this period was similar between treatments, but the loss of BCS tended to be greater for cows previously on the LF diet (Table 7).

No differences between treatments were detected in the extent of feed sorting during the lactating period (Table 4)-although, interestingly, cows previously fed the LF diet did not sort for or against the longest ration particles, whereas cows previously fed the CON diet continued to sort against this fraction. Regardless

Table 4. Effect of molasses-based liquid feed supplementation on the sorting $(\%)^{1}$ of dairy cows across the dry period and in the first $28 \mathrm{~d}$ of lactation (mean $\pm \mathrm{SE})$

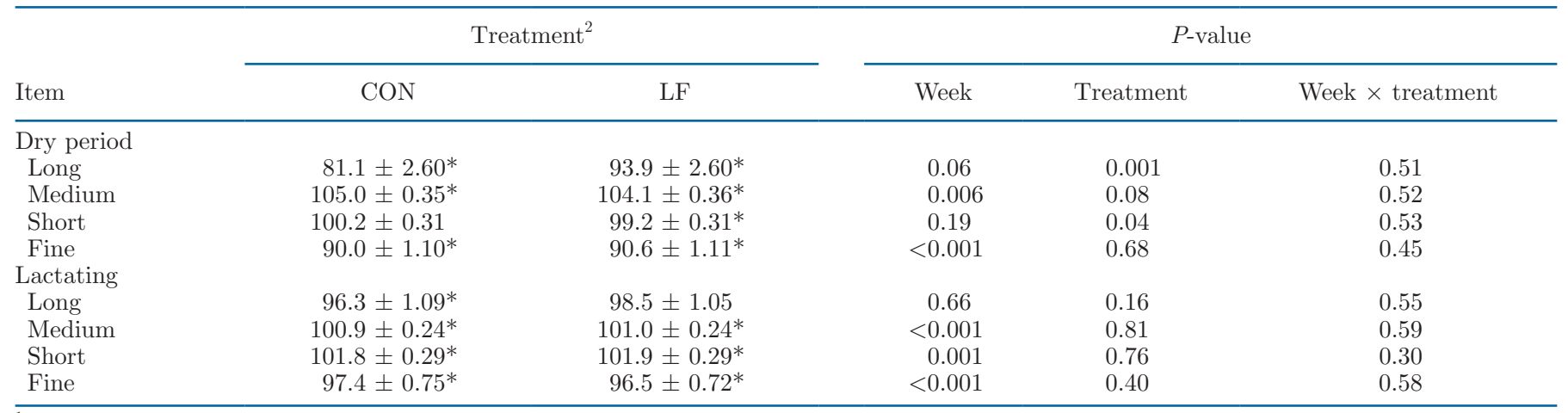

${ }^{1}$ Particle size determined by a Penn State Particle Separator (PSPS), which has a 19-mm screen (long), 8-mm screen (medium), 4-mm screen (short), and a pan (fine). Sorting $\%=$ actual DMI of each particle size fraction/predicted DMI of each particle size fraction $\times 100$. For each fraction, the actual DM amount consumed was calculated by subtracting the DM refused from the DM offered, as determined by the PSPS analyses. The predicted amount consumed for each fraction was calculated as the product of the actual DMI of the total diet $\times$ the DM percentage of that fraction in the fed TMR. Sorting $\%=100$ means no sorting occurred; sorting $\%<100$ means sorting occurred against; and sorting $\%>100$ means sorting occurred in favor.

${ }^{2} \mathrm{CON}=$ control, dry diet with no molasses supplementation; LF = liquid feed-supplemented diet, dry diet with molasses supplementation at a rate of $1.0 \mathrm{~kg} / \mathrm{cow}$ per day.

${ }^{*} P<0.05=$ difference in sorting from $100 \%$. 
Table 5. Effect of molasses-based liquid feed supplementation throughout the dry period on reticulorumen pH throughout the dry period and the first $28 \mathrm{~d}$ of lactation (mean $\pm \mathrm{SE}$ )

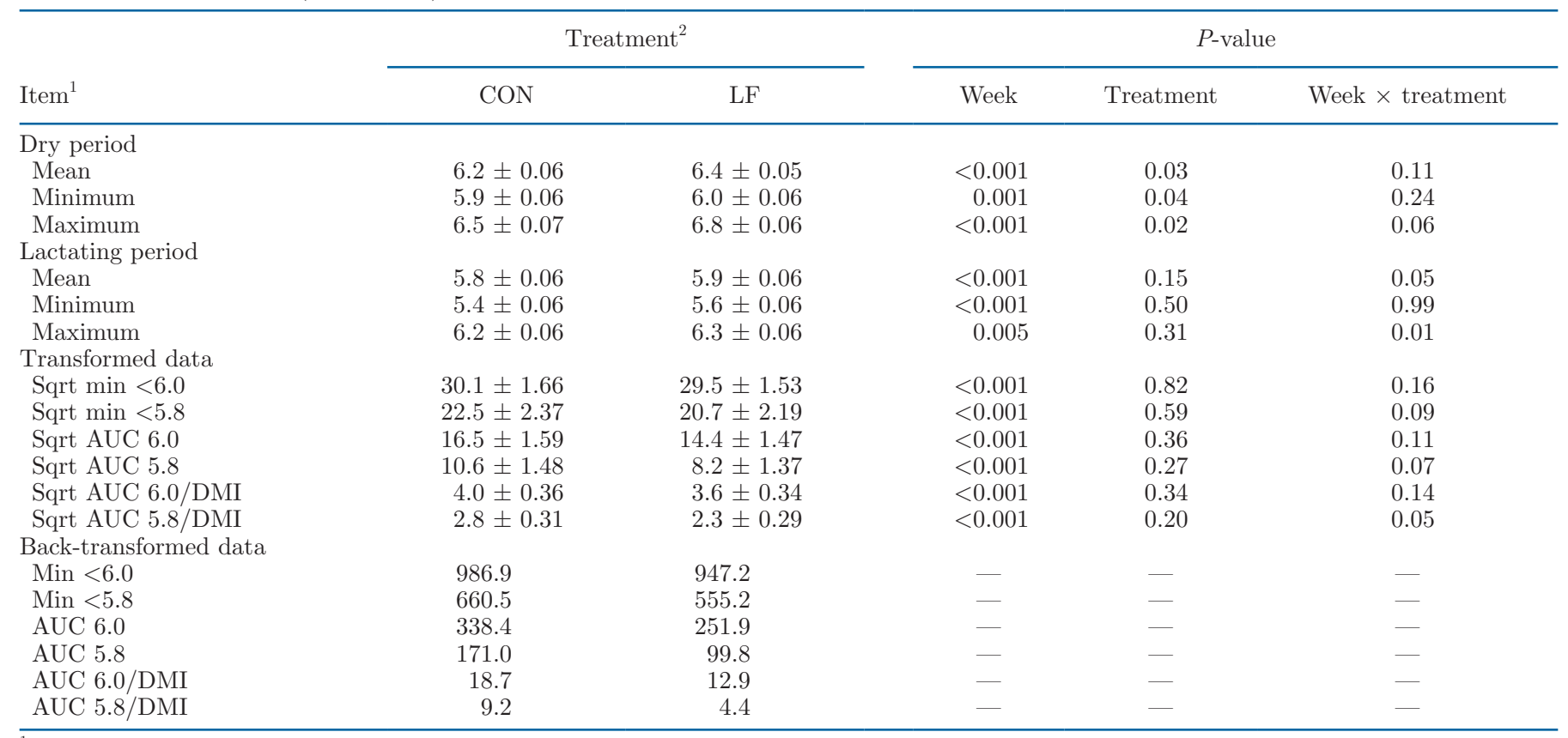

${ }^{1}$ Sqrt $=$ square root transformation; a value of 1 was added to all values before the transformation to ensure the square root could be calculated for all data points equal to $0 . \mathrm{AUC}=$ area under the curve $(\mathrm{pH} \times \min / \mathrm{d})$. AUC/DMI $=$ area under the $\mathrm{curve} \mathrm{pH}<5.8$ or $<6.0(\mathrm{pH} \times \mathrm{min} / \mathrm{d})$ divided by DMI $(\mathrm{kg} / \mathrm{d})$.

${ }^{2} \mathrm{CON}=$ control, dry diet with no molasses supplementation $(\mathrm{n}=10$ cows $) ; \mathrm{LF}=$ liquid feed-supplemented diet, dry diet with molasses supplementation at a rate of $1.0 \mathrm{~kg} / \mathrm{cow}$ per day ( $\mathrm{n}=15$ cows).

of treatment, cows sorted in favor of the medium-length particles, in favor of the short particles, and against the fine particles.

We discovered a treatment $\times$ week interaction for mean reticulorumen $\mathrm{pH}$ (Table 5). During wk 1 (CON $=5.7 \pm 0.06 \mathrm{pH} ; \mathrm{LF}=5.8 \pm 0.06 \mathrm{pH} ; P=0.04)$ cows fed the LF diet had higher mean reticulorumen $\mathrm{pH}$, and during wk $2(\mathrm{CON}=5.7 \pm 0.06 \mathrm{pH} ; \mathrm{LF}=5.9 \pm$ $0.06 \mathrm{pH} ; P=0.09)$ they tended to have greater mean reticulorumen $\mathrm{pH}$ than cows previously fed the CON diet. During wk 1, cows previously fed the LF diet also had higher maximum reticulorumen $\mathrm{pH}$ than cows previously fed the $\mathrm{CON}$ diet $(\mathrm{CON}=6.0 \pm 0.07 \mathrm{pH}$; $\mathrm{LF}=6.3 \pm 0.06 \mathrm{pH} ; P=0.05)$. The change in mean reticulorumen $\mathrm{pH}$ across the first week post-calving was modeled, and the fitted data indicated treatment differences for linear coefficients $(P<0.001$; Figure 4 ), with cows previously fed the CON diet having a steeper decline in mean reticulorumen $\mathrm{pH}$ in the week after calving compared with cows previously fed the LF diet. When standardized by DMI, we found a treatment $\times$ week interaction (Table 5), with AUC 5.8 being greater during wk 1 ( $P=0.04$; mean, $95 \%$ CI for backtransformed data) for cows previously fed the CON diet compared with cows previously fed the LF $\operatorname{diet}[\mathrm{CON}=$
$16.5(\mathrm{pH} \times \min / \mathrm{d}) /(\mathrm{kg} / \mathrm{d})(9.33,19.26) ; \mathrm{LF}=8.3(\mathrm{pH}$ $\times \min / \mathrm{d}) /(\mathrm{kg} / \mathrm{d})(4.66,11.42)]$.

During the lactating period, we detected no differences between dry diet treatments for any of the blood metabolites measured (Table 6; Figure 5), although cows previously fed the LF diet tended to have, on average, a lesser average maximum BHB reading compared with cows previously fed the CON diet $(\mathrm{CON}$ $=1.5 \pm 0.22 \mathrm{mmol} / \mathrm{L} \mathrm{BHB} ; \mathrm{LF}=0.9 \pm 0.22 \mathrm{mmol} / \mathrm{L}$ BHB; $P=0.06)$. No statistical differences between treatments were detected for milk production (Table 7; Figure 6) and efficiency of production (Table 7). We also detected no treatment effect on milk components, MUN, or SCC (Table 7).

\section{DISCUSSION}

Molasses is an effective source of sugar that can improve microbial efficiency and promote feed intake (Hall, 2002). Several researchers have investigated the effects of adding molasses-based liquid feed to both dry cow (Litherland et al., 2013) and lactating cow diets (Broderick and Radloff, 2004; Penner and Oba, 2009; DeVries and Gill, 2012), although limited research has focused on its effects in high-straw dry cow diets (Lith- 
Table 6. Effect of molasses-based liquid feed supplementation throughout the dry period on blood metabolites throughout the dry period and the first $28 \mathrm{~d}$ of lactation $(\text { mean } \pm \mathrm{SE})^{1}$

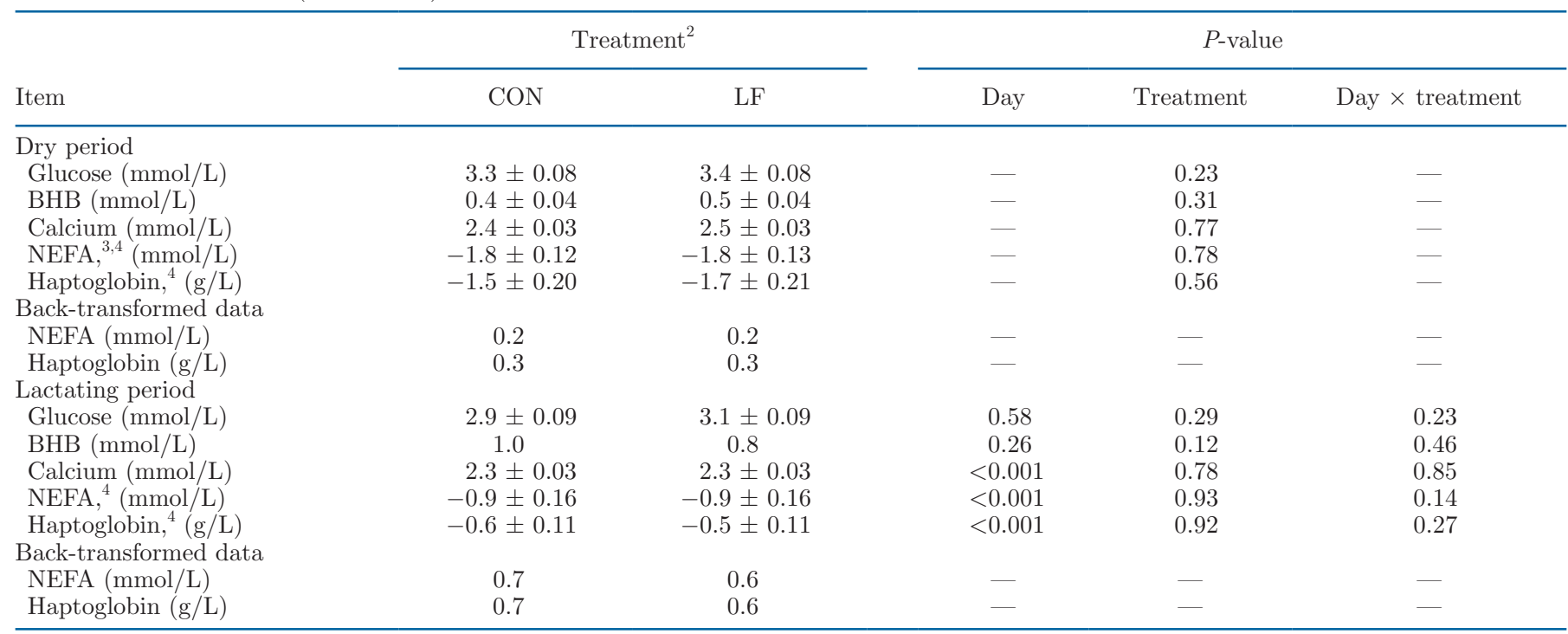

${ }^{1}$ Blood samples were taken on $\mathrm{d}-7,1,4,7$.

${ }^{2} \mathrm{CON}=$ control, dry diet with no molasses supplementation $(\mathrm{n}=20) ; \mathrm{LF}=$ liquid feed-supplemented diet, dry diet with molasses supplementation at a rate of $1.0 \mathrm{~kg} /$ cow per day $(\mathrm{n}=20)$.

${ }^{3} \mathrm{NEFA}=$ nonesterified fatty acid.

${ }^{4} \mathrm{Log}$-transformed data.

erland et al., 2013). Thus, the objective of the current study was to determine whether addition of molassesbased liquid feed to a high-straw dry cow TMR would improve DMI, reduce feed sorting, and improve metabolic health and performance across the transition period. In support of our hypotheses, cows fed the LF diet had greater DMI in the dry period compared with cows fed the CON diet. This finding is consistent with Miller (2011), whose study found that dairy cows fed liquid feed in the dry period had greater feed intake compared with the control group, but inconsistent with the findings of Litherland et al. (2013), that liquid feed supplementation in a dry cow diet did not affect DMI. Despite small differences in the liquid feed composition between Litherland et al. (2013) and the present study, it is noteworthy that the overall diet composition was similar between studies in terms of DM and sugar content. However, more distinct differences existed in

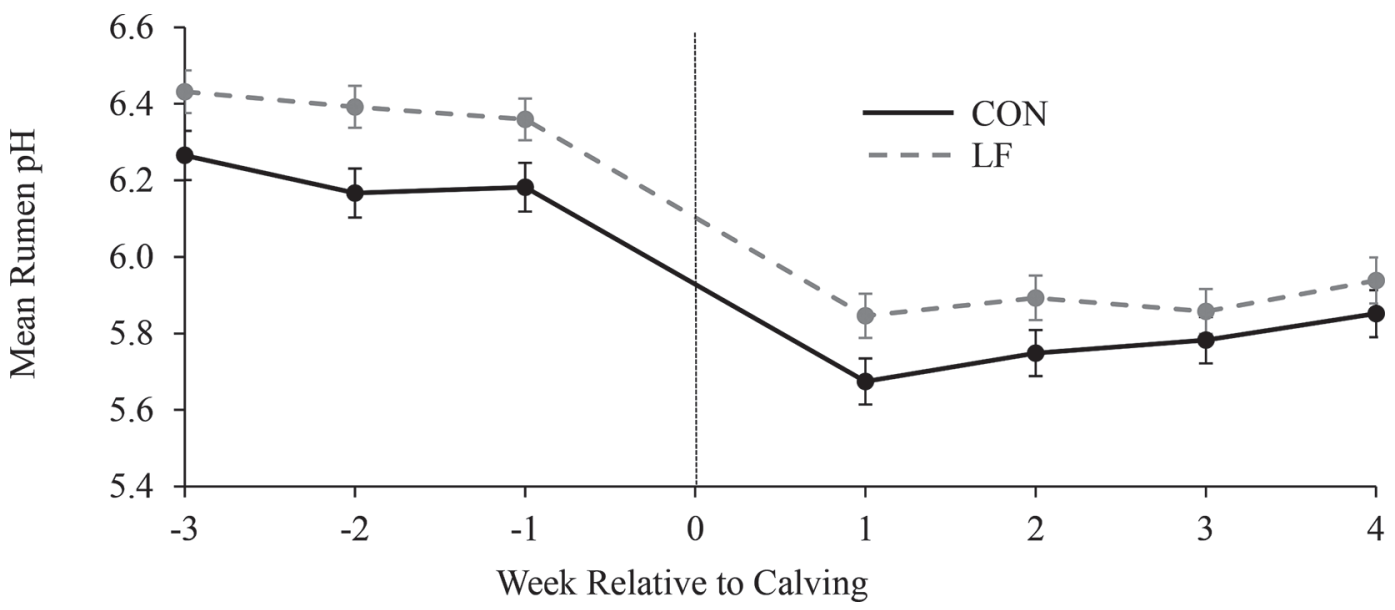

Figure 3. Mean $( \pm \mathrm{SE})$ daily reticulorumen $\mathrm{pH}$ for cows fed 1 of 2 dietary treatments during the dry period: CON = control, dry diet with no molasses supplementation $(\mathrm{n}=10) ; \mathrm{LF}=$ liquid feed-supplemented diet, dry diet with molasses supplementation at a rate $1.0 \mathrm{~kg} / \mathrm{cow}$ per day $(\mathrm{n}=15)$. Upon calving all cows were fed the same lactating cow ration. Vertical line represents calving. 
the mineral contents and DCAD levels between the 2 studies, which is likely the result of the anions added to the liquid feed in the present study. Furthermore, the dry cow diets in the present study had lesser starch content and greater NDF content, and did not contain any supplemental dry corn or alfalfa hay, in contrast with the diets offered by Litherland et al. (2013). The differences in DMI response compared with the findings of Litherland et al. (2013) may be attributable to the base dry cow diet in the present study potentially being less fermentable. Greater DMI, in response to sugar supplementation in a less-fermentable diet, would be predicted given the known benefits of supplementing sugars on rumen microbial populations, fiber digestion (Oba, 2011), and NDF digestibility (Broderick and Radloff, 2004). Also, in agreement with the present study, liquid molasses supplementation increased DMI in both lactating cows (DeVries and Gill, 2012) and calves (Gordon and DeVries, 2016); those researchers attributed this to the greater palatability of diets containing sugars, as it is accepted that cows prefer sweet-tasting feeds (Nombekela et al., 1994; Chiy and Phillips, 1999).

Liquid-based molasses feed has been shown to reduce sorting when added to lactating cow rations, which is facilitated by adhering the smaller particles to the larger particles of the diet (DeVries and Gill, 2012). Contrary to this, the particle distribution of the offered dry cow diets in the present study was not different, which may provide evidence that in a high-straw diet, molasses does not necessarily agglomerate the smaller feed particles to the larger ones. In contrast, Litherland et al. (2013) reported that the addition of liquid molasses increased the proportion of particles on the top screen $(>19 \mathrm{~mm})$ and decreased the proportion of particles in the pan $(<1.18 \mathrm{~mm})$ as a result of the molasses adhering the finest dietary particles to the longer particles. It is also noteworthy that Litherland et al. (2013) reported greater quantities of particles retained on the top screen (particles $>19 \mathrm{~mm}$ ) compared with the present study ( $\sim 12 \%$ vs. $\sim 8 \%)$, and a lesser amount

Table 7. Effect of molasses-based liquid feed supplementation throughout the dry period on BW and BCS change across the transition period, and milk production and composition of lactating dairy cows in the first $28 \mathrm{~d}$ of lactation $(\text { mean } \pm \mathrm{SE})^{1}$

\begin{tabular}{|c|c|c|c|c|c|}
\hline Item & \multicolumn{2}{|c|}{ Treatment $^{2}$} & \multicolumn{3}{|c|}{$P$-value } \\
\hline \multicolumn{6}{|l|}{ Milk yield (kg/d) } \\
\hline $4 \% \mathrm{FCM}$ & $44.6 \pm 1.51$ & $47.1 \pm 1.40$ & $<0.001$ & 0.23 & 0.97 \\
\hline ECM & $47.1 \pm 1.52$ & $49.9 \pm 1.40$ & $<0.001$ & 0.19 & 0.97 \\
\hline \multicolumn{6}{|l|}{ Efficiency of milk production $(\mathrm{kg} / \mathrm{kg})$} \\
\hline \multicolumn{6}{|l|}{ Milk composition (\%) } \\
\hline Fat & $5.1 \pm 0.13$ & $5.2 \pm 0.12$ & $<0.001$ & 0.56 & 0.22 \\
\hline Protein & $3.4 \pm 0.06$ & $3.4 \pm 0.06$ & $<0.001$ & 0.58 & 0.40 \\
\hline \multicolumn{6}{|l|}{ Milk component yield $(\mathrm{kg} / \mathrm{d})$} \\
\hline Fat & $1.0 \pm 0.04$ & $1.0 \pm 0.04$ & 0.48 & 0.31 & 0.81 \\
\hline Protein & $0.6 \pm 0.02$ & $0.7 \pm 0.02$ & 0.01 & 0.12 & 0.14 \\
\hline BCS at enrolment & $3.3 \pm 0.08$ & $3.5 \pm 0.09$ & - & 0.10 & - \\
\hline Dry period change in $\mathrm{BW}^{6}(\mathrm{~kg})$ & $46.3 \pm 9.03$ & $45.8 \pm 9.52$ & - & 0.97 & - \\
\hline Dry period change in $\mathrm{BCS}^{6}$ & $0.18 \pm 0.06$ & $0.17 \pm 0.06$ & - & 0.92 & - \\
\hline Lactating period change in $\mathrm{BW}^{7}(\mathrm{~kg})$ & $-126.0 \pm 12.76$ & $-136.8 \pm 13.49$ & - & 0.57 & - \\
\hline Lactating period change in $\mathrm{BCS}^{7}$ & $-0.45 \pm 0.06$ & $-0.60 \pm 0.06$ & - & 0.08 & - \\
\hline
\end{tabular}

${ }^{1}$ Milk composition was tested on 2 consecutive days per week starting on d 5 for each cow; all values were averaged by cow, by week.

${ }^{2} \mathrm{CON}=$ control, dry diet with no molasses supplementation $(\mathrm{n}=20$ cows $) ; \mathrm{LF}=$ liquid feed-supplemented diet, dry diet with molasses supplementation at a rate of $1.0 \mathrm{~kg} / \mathrm{cow}$ per day $(\mathrm{n}=20$ cows).

${ }^{3} \mathrm{SCC}$ (cells/mL) were log-transformed, given that they did not meet the assumptions of normality.

${ }^{4}$ Back-transformed SCC data.

${ }^{5} \mathrm{BCS}$ was visually assessed and recorded using a 5 -point scale, where $1=$ very thin and $5=$ obese. BW was recorded with a digital walkover scale.

${ }^{6}$ Change in BW and BCS calculated based on pre-calving measurement subtracted from enrolment measurement.

${ }^{7}$ Change in BW and BCS calculated based on end-of-trial measurement subtracted from pre-calving measurement. 
of particles $<8 \mathrm{~mm}(\sim 43 \%$ vs. $\sim 60 \%)$ with a diet containing less straw than the present study ( $\sim 30 \%$ vs. $\sim 33-36 \%$ ), which indicates that the particle size of the straw in that study was longer than that used in the present study. In the present study, cows sorted against the longest dietary particles regardless of treatment; however, cows fed the LF diet sorted less against these particles than did cows fed the CON diet. This finding is consistent with DeVries and Gill (2012), who found that cows sorted less when liquid feed was added to a lactating diet, but inconsistent with the results of Litherland et al. (2013), where no sorting occurred, or increased sorting occurred with the addition of liquid feed. Specifically, Litherland et al. (2013) reported no differences in sorting when liquid feed was added to the dry cow diet but reported that cows tended to sort more against particles on the top 2 screens $(>19.0$ to $8.0 \mathrm{~mm}$ in length) when liquid feed was added to a lactating diet. Cows will sort a diet where particle size is more easily distinguished (Oelker et al., 2009); as such, it may be possible that lactating cows in the Litherland et al. (2013) study sorted more against the long particles because that diet contained a greater proportion of long particles on the top 2 screens as a result of liquid feed inclusion, making the long dietary particles in their diet more distinguishable. Interestingly, Havekes et al. (2020b) reported a similar reduction, compared with the current study, in degree of sorting against the longest ration particles when water was added to a high-straw dry cow diet compared with when cows were fed a diet with no added water. It is noteworthy that the liquid feed addition in the current study did not drastically influence the overall DM content of the ration compared with that of the CON diet; accordingly, the observed results in this research are more likely related to non-moisture factors. That being said, the DM content of the tested dry cow diets was greater than field recommendations; thus, future research is needed to determine whether reducing the moisture content, coupled with the addition of molasses, could further reduce and potentially eliminate sorting when cows are fed high-straw dry cow diets. Lastly, the liquid feed supplement fed in Litherland et al. (2013) had higher DM content ( $\sim 63 \%$ vs. $\sim 48 \%)$ and was fed at a lesser rate $(0.86 \mathrm{~kg}$ vs. $1.0 \mathrm{~kg}$ on a DM basis) compared with the present study, which may also have contributed to the differences in sorting results between the 2 studies.

Cows fed the CON diet did not sort for or against the short dietary particles, but cows fed the LF diet sorted against these particles, and regardless of treatment, cows sorted against the fine particles. This is surprising, as typically cows sort in favor of the palatable concentrate fractions of the diet; however, recent studies of high-straw dry cow diets (Havekes et al., 2020a,b) have

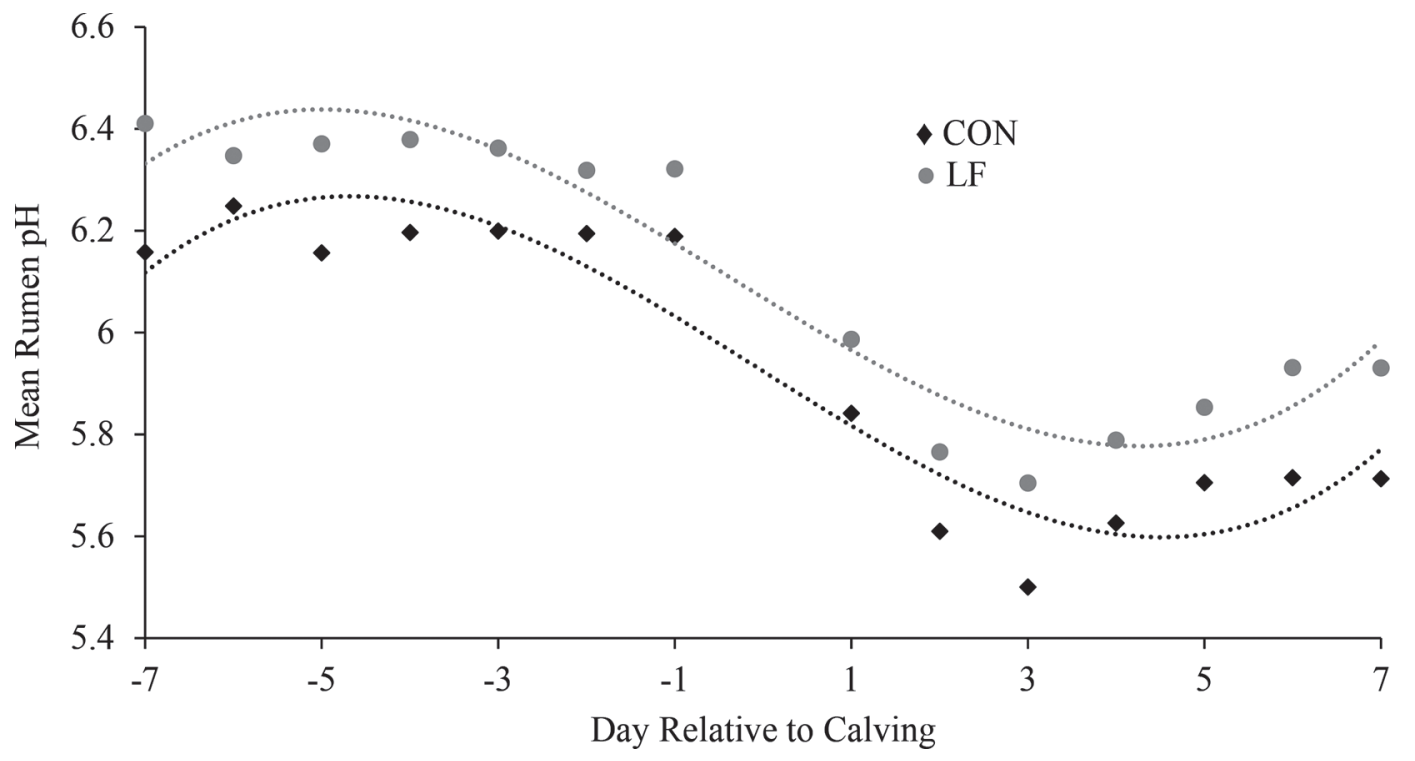

Figure 4. Mean daily reticulorumen $\mathrm{pH}$ for cows 1 wk pre-calving to 1 wk post-calving when cows were fed 1 of 2 dietary treatments during the dry period: $\mathrm{CON}=$ control, dry diet with no molasses supplementation $(\mathrm{n}=10) ; \mathrm{LF}=$ liquid feed-supplemented diet, dry diet with molasses supplementation at a rate $1.0 \mathrm{~kg} / \mathrm{cow}$ per day $(\mathrm{n}=15)$. Upon calving all cows were fed the same lactating cow ration. Trend lines were constructed using analysis of covariance: $\mathrm{y}=-0.62 \mathrm{~d}+0.16 \mathrm{~d}^{2}-0.01 \mathrm{~d}^{3}+6.32\left(\mathrm{R}^{2}=0.90\right)$ for $\mathrm{CON} ; \mathrm{y}=-0.61 \mathrm{~d}+0.16 \mathrm{~d}^{2}-0.01 \mathrm{~d}^{3}+$ $6.46\left(\mathrm{R}^{2}=0.92\right)$ for $\mathrm{LF}$. 
reported similar results, with cows sorting against these fractions - likely, as discussed therein, because those finer fractions contained mostly straw dust and fines.
After calving, cows fed the LF diet did not sort for or against the long dietary particles, but cows fed the $\mathrm{CON}$ diet continued to sort against these particles. Past
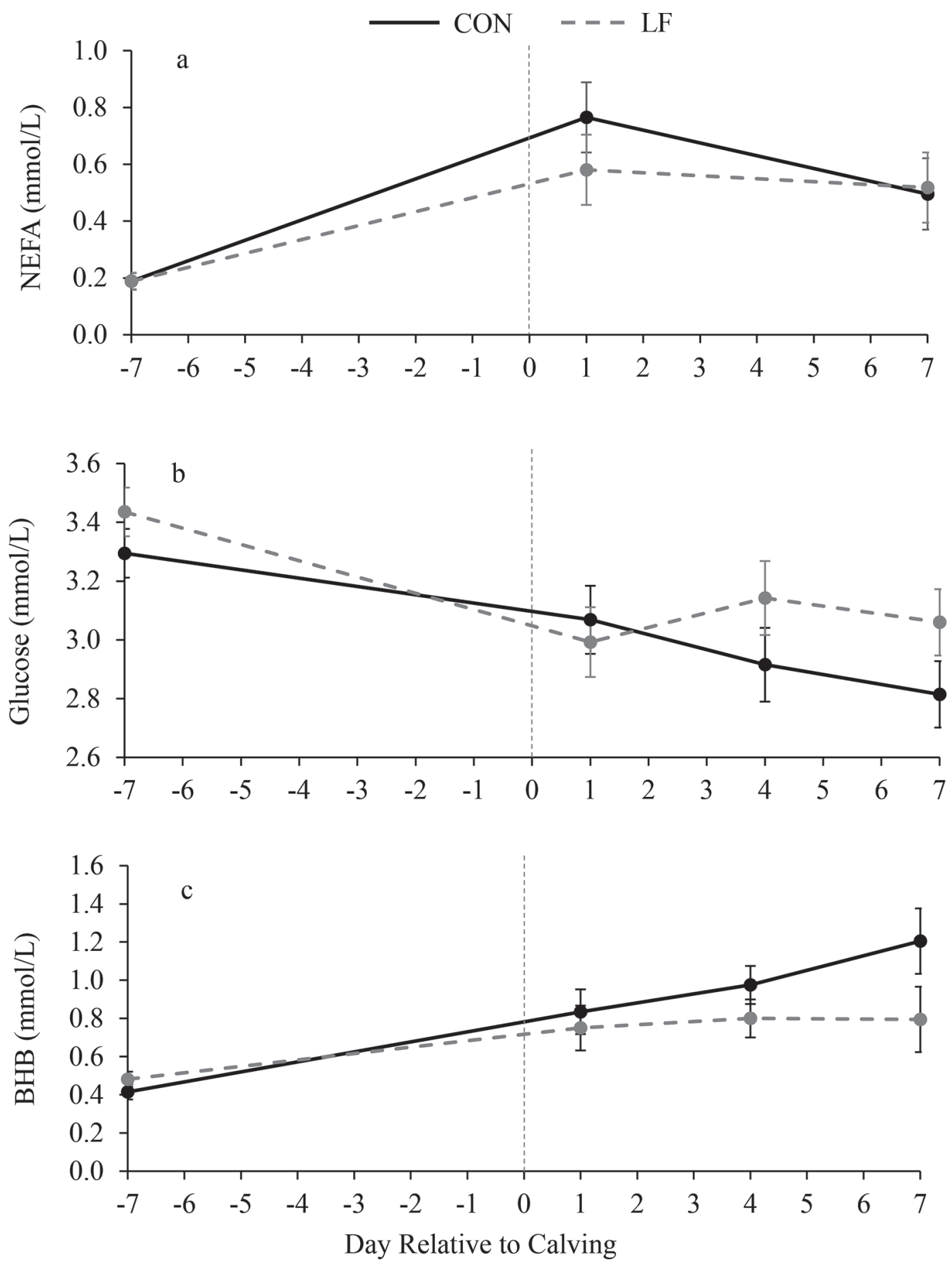

Figure 5. Mean $( \pm \mathrm{SE})$ for (a) serum nonesterified fatty acids (NEFA, mmol/L), (b) whole-blood glucose $(\mathrm{mmol} / \mathrm{L})$, and $(\mathrm{c})$ whole-blood BHB $(\mathrm{mmol} / \mathrm{L})$ for cows fed 1 of 2 dietary treatments during the dry period: $\mathrm{CON}=$ control, dry diet with no molasses supplementation $(\mathrm{n}=$ 20); LF = liquid feed-supplemented diet, dry diet with molasses supplementation at a rate of $1.0 \mathrm{~kg} / \mathrm{cow}$ per day $(\mathrm{n}=20)$. Upon calving all cows were fed the same lactating cow ration. Vertical line represents calving. 

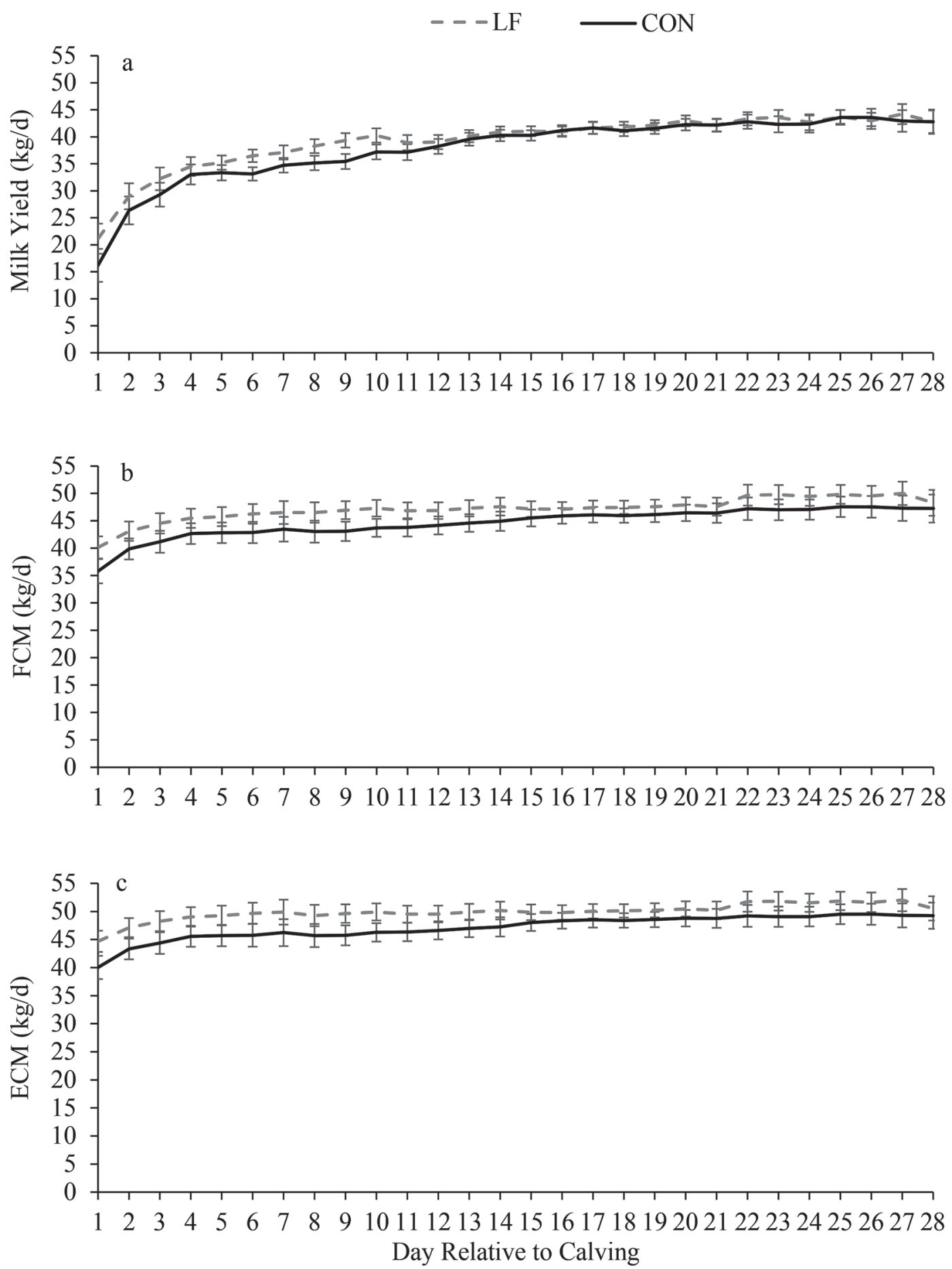

Figure 6. Mean daily values $( \pm \mathrm{SE}$ ) for (a) milk yield $(\mathrm{kg} / \mathrm{d})$, (b) $4.0 \% \mathrm{FCM}$ yield $(\mathrm{kg} / \mathrm{d})$, and (c) ECM yield (kg/d) for cows fed 1 of 2 dietary treatments during the dry period: $\mathrm{CON}=$ control, dry diet with no molasses supplementation $(\mathrm{n}=20)$ : LF $=$ liquid feed-supplemented diet, dry diet with molasses supplementation at a rate of $1.0 \mathrm{~kg} / \mathrm{cow}$ per day $(\mathrm{n}=20)$. Upon calving all cows were fed the same lactating cow ration.

research with calves has demonstrated that if calves are provided with a sortable diet, and if they learn the sorting behavior before a dietary change, they are more likely to continue the behavior after they transition onto a new diet (Miller-Cushon et al., 2013). Although cows fed the LF diet did sort against the long particles pre-calving, they did not sort to the same degree as the cows fed the CON diet. Thus, it is possible that the 
cows fed the LF diet did not carry over the behavior to the same extent as cows fed the CON diet. These results provide promising evidence that providing a less-sortable diet pre-calving may reduce feed sorting post-calving - a time when the consequences of consuming an imbalanced diet are more severe.

To our knowledge, in no other work have the effects of molasses-based liquid feed on the feeding behavior of dry cows been investigated. Cows fed the LF diet consumed their feed more quickly and spent numerically less time on a given meal compared with cows fed the CON diet. This is likely reflective of the differences in sorting between the 2 treatments, as it has previously been shown that cows that sort more will spend more time distinguishing particles from one another, thus increasing their meal time and slowing their feeding rate (Greter and DeVries, 2011). Furthermore, Chiy and Phillips (1999) reported that cows consume sweet flavors more quickly than bitter and salty flavors, which may also explain why cows fed the LF treatment had a faster feeding rate than cows fed the CON diet in our study. Interestingly, cows fed the LF diet also tended to have more frequent meals and tended to have shorter intervals between meals, without consuming more feed within a meal, compared with cows fed the CON diet. This finding may be associated with sugar having an enhancing effect on fiber-digesting bacteria, improving microbial efficiency and overall digestibility (Martel et al., 2011; Oba, 2011). Increased digestibility of a ration would result in faster rates of passage, allowing the cow to consume more DM more frequently (Allen, 1996), which is likely what drove the increased meal frequency and decreased interval between meals, as well as the total increase in DMI, reported in the current study when cows were fed the LF diet.

Rumen health was better for cows fed the LF diet, as demonstrated by their higher mean $\mathrm{pH}$ levels in the dry period and in the first week of lactation. This finding is consistent with previous research on lactating cows, when cows fed diets with added sugar showed reduced $\mathrm{NH}_{3}$ concentrations and higher mean $\mathrm{pH}$ compared with control groups (Broderick and Radloff, 2004; Penner and Oba, 2009; Martel et al., 2011). Furthermore, during the first 2 wk after calving, cows fed the LF diet had higher mean $\mathrm{pH}$ compared with cows fed the CON diet. This is likely related to cows fed the LF diet having more consistent intake leading up to calving, coupled with cows fed the LF diet not sorting for or against the longest particles, resulting in a more stable rumen environment (DeVries et al., 2008). Furthermore, feeding sugars has also been demonstrated to increase butyrate production in the rumen, which increases blood flow to the ruminal epithelium and results in an increased gradient between the rumen and the epithelial cells (Martel et al., 2011). Martel et al. (2011) further concluded that this increased uptake of VFA from the rumen resulted in higher mean rumen $\mathrm{pH}$. Although VFA concentrations in the rumen or blood were not measured in this study, if the rumen epithelium was improved in the dry period from the addition of molasses, it may have carried over into lactation, resulting in better rumen health. This assumption is supported by the work of Steinwidder et al. (2015), who demonstrated that cows with lower mean and minimum $\mathrm{pH}$ values pre-calving had lower mean and minimum $\mathrm{pH}$ values after calving as well, suggesting that rumen health characteristics may carry over from gestation to lactation. Moreover, when standardized for DMI post-calving, cows fed the CON diet had a greater AUC at the $\mathrm{pH}$ threshold of 5.8 , which indicates that cows fed the CON diet were experiencing a greater degree of ruminal acidosis during early lactation than cows fed the LF diet were. If improvements to the rumen epithelium in the dry period did, in fact, result in a healthier rumen post-calving, this finding makes sense. Similarly, Penner and Oba (2009) reported that early-lactation cows fed sucrose spent numerically less time experiencing ruminal $\mathrm{pH}$ $<5.8$ compared with cows fed no sucrose (174 vs. 322 $\mathrm{min} / \mathrm{d}$ ). Lastly, given that sugar supplementation has proven to facilitate fiber digestion and improve rumen health (Penner and Oba, 2009; Oba, 2011), the discontinuation of feeding liquid molasses at parturition may have changed the balance of carbohydrates supplied to the rumen. Despite this, LF cows still had remarkably better rumen health post-calving, which warrants future research to investigate the effects on ruminal health of providing molasses-based liquid feed in both the dry and lactating period.

We detected no differences between treatments for any blood metabolites measured during the dry period. This is not surprising, as cows are at low risk of experiencing metabolic issues when energy demands are low. Contrary to this finding, Litherland et al. (2013) reported that pre-calving NEFA and BHB levels were greater for cows fed molasses-based liquid feed compared with a control group. Those authors attributed this finding to the tendency for cows fed the molasses to have lesser DMI relative to the control group (Litherland et al., 2013). In the present study, LF cows consumed more DM compared with the CON group, but because the dietary energy density and intakes across both treatments were greater than predicted, neither CON nor LF cows were limited in energy before calving. Research on pregnant ewes reports that ewes supplemented with molasses had 19\% higher glucose levels in the week before lambing, compared with a control group (Moaellem et al., 2016). Although not significantly different, glucose levels followed a similar 
trend in the present study, with cows fed the LF diet having numerically higher blood glucose levels in the week leading up to calving. Post-calving, cows fed the LF diet continued to exhibit numerically higher glucose levels, which may be reflective of LF cows having greater rumen papillae absorptive capacity. Moreover, cows fed the LF diet tended to have a lower average maximum $\mathrm{BHB}$ reading compared with cows fed the $\mathrm{CON}$ diet in the first week post-calving. Cows fed the CON diet, on average, had maximum BHB levels indicative of subclinical ketosis, whereas cows fed the LF diet did not, on average, reach the $1.2 \mathrm{mmol} / \mathrm{L}$ threshold. Given that cows with blood BHB concentrations greater than $1.1 \mathrm{mmol} / \mathrm{L}$ are anywhere from 4.7 to 14.7 times more likely to develop clinical signs of ketosis (Benedet et al., 2019), this becomes a very important finding. Furthermore, this finding agrees with that of Goldhawk et al. (2009), where it was reported that decreased DMI precalving increases the risk of experiencing subclinical ketosis post-calving. However, this finding is contrary to Litherland et al. (2013), where dry cows supplemented with molasses had higher BHB levels postpartum compared with control cows. It becomes difficult to compare these results with those of the current study, because Litherland et al. (2013) continued to feed molasses postpartum, whereas the current study did not. To our knowledge, no other research has investigated how prepartum molasses supplementation influenced post-calving metabolic health in dairy cows.

Lastly, no treatment difference was detected for milk production and components, although LF-fed cows had numerically greater daily yields of milk, ECM, and FCM, as well as greater efficiency of production. Interestingly, Litherland et al. (2013) reported increased $3.5 \%$ FCM efficiency when cows were fed liquid feed in both the dry period and for the first $56 \mathrm{~d}$ postpartum. In one regard, the lack of statistical difference in milk yield in the present study is not overly surprising, considering DMI drives milk yield and no differences were detected in postpartum DMI between treatments. However, the lack of detected difference in milk yield and component yield is somewhat surprising when the loss of body condition between treatments is considered. It is still noteworthy that the numerical increases in FCM $(+2.5 \mathrm{~kg} / \mathrm{d})$, ECM $(+2.8 \mathrm{~kg} / \mathrm{d})$, and efficiency $(+0.2$ percentage points) could help partially explain the increased loss of body condition for cows fed the LF diet. The lack of statistical significance for these outcomes could be related to sample size: for example, the observed $2.5-\mathrm{kg} / \mathrm{d}$ numerical difference in FCM yield between treatments was an increase of only $5 \%$; based on our sample size and observed variation in milk production, our study only had sufficient power to detect a difference of $7.6 \%$.

\section{CONCLUSIONS}

Supplementing high-straw dry cow diets with a molasses-based liquid feed was demonstrated to be an effective strategy for increasing DMI, reducing feed sorting, and promoting more consistent intake in the period leading up to calving. Furthermore, molasses supplementation during the dry period resulted in improved rumen health, as demonstrated by higher mean reticulorumen $\mathrm{pH}$ in the dry period and more consistent mean reticulorumen $\mathrm{pH}$ in the first week after calving.

\section{ACKNOWLEDGMENTS}

Thank you to the staff of the University of Guelph, Elora Research Station-Dairy Facility (Elora, ON, Canada), and especially to Laura Wright for all her assistance and patience in facilitating this research project. Special thanks to Kaitlyn Dancy, Meagan King, Sarah Parsons, and Sydney Moore of the University of Guelph (Guelph, ON, Canada) for their assistance with data collection. This project received financial supported from a Natural Sciences and Engineering Research Council of Canada (NSERC; Ottawa, ON, Canada) Collaborative Research and Development Grant with Liquid Feeds International (Innerkip, ON, Canada), from Quality Liquid Feeds (Dodgeville, WI), as well as the Ontario Agri-Food Innovation Alliance Research Program of the University of Guelph and the Ontario Ministry of Agriculture, Food, and Rural Affairs (Guelph). Further, project equipment was supported by contributions from the Canadian Foundation for Innovation (CFI; Ottawa) and the Ontario Research Fund (Toronto, ON, Canada). The authors have not stated any conflicts of interest.

\section{REFERENCES}

Allen, M. S. 1996. Physical constraints on voluntary intake of forages by ruminants. J. Anim. Sci. 74:3063-3075. https://doi.org/10 $.2527 / 1996.74123063 x$.

AOAC International. 2000. Official Methods of Analysis. Vol. I. 17th ed. AOAC International, Arlington, VA.

Benedet, A., C. L. Manuelian, A. Zidi, M. Penasa, and M. De Marchi. 2019. Invited review: $\beta$-Hydroxybutyrate concentration in blood and milk and its associations with cow performance. Animal 13:1676-1689. https://doi.org/10.1017/S175173111900034X.

Broderick, G. A., and W. J. Radloff. 2004. Effect of molasses supplementation on the production of lactating dairy cows fed diets based on alfalfa and corn silage. J. Dairy Sci. 87:2997-3009. https: //doi.org/10.3168/jds.S0022-0302(04)73431-1.

Canadian Council on Animal Care. 2009. Guidelines On: The Care and Use of Farm Animals in Research, Teaching and Testing. Canadian Council on Animal Care, Ottawa, ON, Canada.

Chapinal, N., D. M. Veira, D. M. Weary, and M. A. G. von Keyserlingk. 2007. Technical note: Validation of a system for monitoring individual feeding and drinking behavior and intake in group-housed cattle. J. Dairy Sci. 90:5732-5736. https://doi.org/ $10.3168 /$ jds.2007-0331. 
Chiy, P. C., and C. J. C. Phillips. 1999. The rate of intake of sweet, salty, and bitter concentrates by dairy cows. Anim. Sci. 68:731740. https://doi.org/10.1017/S1357729800050761.

Constable, P. D., K. W. Hinchcliff, S. H. Done, and W. Grünberg. 2017. Metabolic and endocrine diseases. Pages 1662-1757 in Veterinary Medicine. 11th ed. W.B. Saunders, Philadelphia, PA.

Coon, R. E., T. F. Duffield, and T. J. DeVries. 2018. Effect of straw particle size on the behavior, health, and production of early-lactation dairy cows. J. Dairy Sci. 101:6375-6387. https://doi.org/10 $.3168 /$ jds.2017-13920.

Dancy, K. M., E. S. Ribiero, and T. J. DeVries. 2019. Effect of dietary transition at dry off on the behavior and physiology of dairy cows. J. Dairy Sci. 102:4387-4402. https://doi.org/10.3168/jds.2018 $-15718$.

Dann, H. M., N. B. Litherland, J. P. Underwood, M. Bionaz, A. D'Angelo, J. W. McFadden, and J. K. Drackley. 2006. Diets during far-off and close-up dry periods affect periparturient metabolism and lactation in multiparous cows. J. Dairy Sci. 89:3563-3577. https://doi.org/10.3168/jds.S0022-0302(06)72396-7.

DeVries, T. J., F. Dohme, and K. A. Beauchemin. 2008. Repeated ruminal acidosis challenges in lactating dairy cows at high and low risk for developing acidosis: Feed sorting. J. Dairy Sci. 91:3958 3967. https://doi.org/10.3168/jds.2008-1347.

DeVries, T. J., and R. M. Gill. 2012. Adding liquid feed to a total mixed ration reduces feed sorting behavior and improves productivity of lactating dairy cows. J. Dairy Sci. 95:2648-2655. https:// doi.org/10.3168/jds.2011-4965.

DeVries, T. J., T. Schwaiger, K. A. Beauchemin, and G. B. Penner. 2014. The duration of time that beef cattle are fed a high-grain diet affects feed sorting behavior both before and after acute ruminal acidosis. J. Anim. Sci. 92:1728-1737. https://doi.org/10.2527/ jas.2013-7252.

DeVries, T. J., M. A. G. von Keyserlingk, D. M. Weary, and K. A. Beauchemin. 2003. Measuring the feeding behavior of lactating dairy cows in early to peak lactation. J. Dairy Sci. 86:3354-3361. https://doi.org/10.3168/jds.S0022-0302(03)73938-1.

Drackley, J. K. 1999. Biology of dairy cows during the transition period: The final frontier? J. Dairy Sci. 82:2259-2273. https://doi .org/10.3168/jds.S0022-0302(99)75474-3.

Falk, M., A. Münger, and F. Dohme-Meier. 2016. Technical note: A comparison of reticular and ruminal $\mathrm{pH}$ monitored continuously with 2 measurement systems at different weeks of early lactation. J. Dairy Sci. 99:1951-1955. https://doi.org/10.3168/jds.2015-9725.

Goldhawk, C., N. Chapinal, D. M. Veira, D. M. Weary, and M. A. G. von Keyserlingk. 2009. Prepartum feeding behavior is an early indicator of subclinical ketosis. J. Dairy Sci. 92:4971-4977. https:/ /doi.org/10.3168/jds.2009-2242.

Gordon, L. J., and T. J. DeVries. 2016. Technical note: Impact of a molasses-based liquid feed supplement on the feed sorting behavior and growth of grain-fed veal calves. J. Anim. Sci. 94:3519-3526. https://doi.org/10.2527/jas.2015-0195.

Greter, A. M., and T. J. DeVries. 2011. Effect of feeding amount on the feeding and sorting behavior of lactating dairy cattle. Can. J. Anim. Sci. 91:47-54. https://doi.org/10.4141/CJAS10067.

Grummer, R. R. 1995. Impact of changes in organic nutrient metabolism on feeding the transition dairy cow. J. Anim. Sci. 73:28202833. https://doi.org/10.2527/1995.7392820x.

Hall, M. B. 2002. Working with sugars (and molasses). Pages 146-158 in Proc. 13th Annu. Florida Ruminant Nutrition Symp. University of Florida, Gainesville, FL.

Havekes, C. D., T. F. Duffield, A. J. Carpenter, and T. J. DeVries. 2020a. Effects of wheat straw chop length in high-straw dry cow diets on intake, health, and performance of dairy cows across the transition period. J. Dairy Sci. 103:254-271. https://doi.org/10 .3168/jds.2019-17033.

Havekes, C. D., T. F. Duffield, A. J. Carpenter, and T. J. DeVries. 2020b. Moisture content of high-straw dry cow diets affects intake, health, and performance of transition dairy cows. J. Dairy Sci. 103:1500-1515. https://doi.org/10.3168/jds.2019-17557.
Heinrichs, A. J. 2013. The Penn State Particle Separator. Extension publication DSE 2013-186. Pennsylvania State University, College Park, PA.

Herdt, T. H. 2000. Ruminant adaptation to negative energy balance. Vet. Clin. North Am. Food Anim. Pract. 16:215-230.

Humer, E., K. Ghareeb, H. Harder, E. Mickdam, A. Khol-Parisini, and Q. Zebeli. 2015. Peripartal changes in reticuloruminal $\mathrm{pH}$ and temperature in dairy cows differing in the susceptibility to subacute rumen acidosis. J. Dairy Sci. 98:8788-8799. https://doi.org/ 10.3168/jds.2015-9893.

Ingvartsen, K. L. 2006. Feeding- and management-related diseases in the transition cow: Physiological adaptations around calving to reduce feeding-related diseases. Anim. Feed Sci. Technol. 126:175213. https://doi.org/10.1016/j.anifeedsci.2005.08.003.

Janovick, N. A., Y. R. Boisclair, and J. K. Drackley. 2011. Prepartum dietary energy intake affects metabolism and health during the periparturient period in primiparous and multiparous Holstein cows. J. Dairy Sci. 94:1385-1400. https://doi.org/10.3168/jds.2010 -3303 .

Kanz, P., M. Drillich, D. Klein-Jöbstl, B. Mair, S. Borchardt, L. Meyer, I. Schwendenwein, and M. Iwersen. 2015. Suitability of capillary blood obtained by a minimally invasive lancet technique to detect subclinical ketosis in dairy cows by using 3 different electronic hand-held devices. J. Dairy Sci. 98:6108-6118. https://doi .org/10.3168/jds.2014-8957.

Leonardi, C., and L. Armentano. 2003. Effect of quantity, quality, and length of alfalfa hay on selective consumption by dairy cows. J. Dairy Sci. 86:557-564. https://doi.org/10.3168/jds.S0022 -0302(03)73634-0.

Litherland, N. B., D. N. L. da Silva, W. P. Hansen, L. Davis, S. Emanuele, and H. Blalock. 2013. Effects of prepartum controlled-energy wheat straw and grass hay diets supplemented with starch or sugar on periparturient dairy cow performance and lipid metabolism. J. Dairy Sci. 96:3050-3063. https://doi.org/10.3168/jds.2012-5998.

MacDonald, P. D. M., and P. E. J. Green. 1988. User's Guide to Program MIX: An Interactive Program for Fitting Mixtures of Distributions. Ichthus Data Systems, Hamilton, Canada.

Martel, C. A., E. C. Titgemeyer, L. K. Mamedova, and B. J. Bradford. 2011. Dietary molasses increases ruminal $\mathrm{pH}$ and enhances ruminal biohydrogenation during milk fat depression. J. Dairy Sci 94:3995-4004. https://doi.org/10.3168/jds.2011-4178.

Maulfair, D. D., and A. J. Heinrichs. 2013. Effects of varying forage particle size and fermentable carbohydrates on feed sorting, ruminal fermentation, and milk and component yields of dairy cows. J. Dairy Sci. 96:3085-3097. https://doi.org/10.3168/jds.2012-6048.

Miller, W. F. 2011. Influence of cane molasses inclusion to dairy cow diets during the transition period on rumen epithelial development and a proposed mechanism of rumen epithelial development. $\mathrm{PhD}$ thesis. Department of Animal Sciences and Industry, College of Agriculture, Kansas State Univ., Manhattan, KS.

Miller-Cushon, E. K., and T. J. DeVries. 2017. Feed sorting in dairy cattle: Causes, consequences, and management. J. Dairy Sci 100:4172-4183. https://doi.org/10.3168/jds.2016-11983.

Miller-Cushon, E. K., C. Montoro, A. Bach, and T. J. DeVries. 2013. Effect of early exposure to mixed rations differing in forage particle size on feed sorting of dairy calves. J. Dairy Sci. 96:3257-3264. https://doi.org/10.3168/jds.2012-6415.

Moallem, U., A. Rosov, H. Honig, I. Ofir, L. Livshits, and E. Gootwine. 2016. Molasses-based supplement improved the metabolic status of late-pregnant ewes bearing multiple fetuses. Anim. Feed Sci. Technol. 219:83-93. https://doi.org/10.1016/j.anifeedsci.2016 .06 .002 .

Morris, T. R. 1999. Experimental design and analysis in animal sciences. CABI Publishing, New York, NY.

NRC (National Research Council). 2001. Nutrient Requirements of Dairy Cattle. 7th rev. ed. Natl. Acad. Press, Washington, DC.

Nombekela, S. W., M. R. Murphy, H. W. Gonyou, and J. I. Marden. 1994. Dietary preferences in early lactation cows as affected by primary tastes and some common feed flavors. J. Dairy Sci. 77:23932399. https://doi.org/10.3168/jds.S0022-0302(94)77182-4. 
Oba, M. 2011. Review: Effects of feeding sugars on productivity of lactating dairy cows. Can. J. Anim. Sci. 91:37-46. https://doi.org/ 10.4141/CJAS10069.

Oelker, E. R., C. Reveneau, and J. L. Firkins. 2009. Interaction of molasses and monensin in alfalfa hay- or corn silage-based diets on rumen fermentation, total tract digestibility, and milk production by Holstein cows. J. Dairy Sci. 92:270-285. https://doi.org/ 10.3168/jds.2008-1432.

Penner, G. B., and M. Oba. 2009. Increasing dietary sugar concentration may improve dry matter intake, ruminal fermentation, and productivity of dairy cows in the postpartum phase of the transition period. J. Dairy Sci. 92:3341-3353. https://doi.org/10.3168/ jds.2008-1977.

Rathbun, F. M., R. S. Pralle, S. J. Bertics, L. E. Armentano, K. Cho, C. Do, K. A. Weigel, and H. M. White. 2017. Relationship between body condition score change, prior mid-lactation phenotypic residual feed intake, and hyperketonemia onset in transition dairy cows. J. Dairy Sci. 100:3685-3696. https://doi.org/10.3168/ jds.2016-12085.

SAS Institute Inc. 2013. SAS Version 9.4. SAS Institute Inc., Cary, $\mathrm{NC}$.

Schirmann, K., M. A. G. von Keyserlingk, D. M. Weary, D. M. Veira, and W. Heuwieser. 2009. Technical note: Validation of a system for monitoring rumination in dairy cows. J. Dairy Sci. 92:6052-6055. https://doi.org/10.3168/jds.2009-2361.

Schwaiger, T., K. A. Beauchemin, and G. B. Penner. 2013. The duration of time that beef cattle are fed a high-grain diet affects the recovery from a bout of ruminal acidosis: Dry matter intake and rumen fermentation. J. Anim. Sci. 91:5729-5742. https://doi.org/ 10.2527/jas.2013-6471.

Steinwidder, A., M. Horn, R. Pfister, H. Rohrer, and J. Gasteiner. 2015. Close relationship between pre- and post-calving reticuloruminal pH levels in dairy cows. Livest. Sci. 178:177-182. https://doi .org/10.1016/j.livsci.2015.05.027.

Tyrrell, H. F., and J. T. Reid. 1965. Prediction of the energy value of cow's milk. J. Dairy Sci. 48:1215-1223. https://doi.org/10.3168/ jds.S0022-0302(65)88430-2.

Wildman, E. E., G. M. Jones, P. E. Wagner, R. L. Boman, H. F. Troutt Jr., and T. N. Lesch. 1982. A dairy cow body condition scoring system and its relationship to selected production characteristics. J. Dairy Sci. 65:495-501. https://doi.org/10.3168/jds .S0022-0302(82)82223-6.

Wittrock, J. A., T. F. Duffield, and S. J. LeBlanc. 2013. Short communication: Validation of a point-of-care glucometer for use in dairy cows. J. Dairy Sci. 96:4514-4518. https://doi.org/10.3168/ jds.2012-6533

\section{ORCIDS}

T. F. Duffield (๑) https://orcid.org/0000-0001-6035-4669

A. J. Carpenter $\odot$ https://orcid.org/0000-0002-9779-0779

T. J. DeVries (1) https://orcid.org/0000-0001-9364-2456 